\title{
BUNJEVCI U RANOME NOVOM VIJEKU POSTANAK I RAZVOJ JEDNE PREDMODERNE ETNIJE
}

\author{
Marko ŠARIĆ \\ Filozofski fakultet Sveučilišta u Zagrebu \\ Zavod za hrvatsku povijest \\ Ivana Lučića 3, 10000 Zagreb
}

\section{UVOD}

U mirovljeni vojnokrajiški pukovnik Ivan Murgić u svom je poznatom članku Uspomene na gornju Krajinu s osobitim obzirom na Bunjevce, objavljenom u časopisu Vienac početkom 1882. godine, opisujući pojedina naselja u Primorju i Lici u kojima je službovao počevši od 1828. godine, o tamošnjim stanovnicima zapisao: Svi se ovi još i sada sami zovu Bunjevci i kažu: mi smo vridna braća Bunjevci. (Murgić, 1882:2, 29) ${ }^{1} \mathrm{Na}$ drugom mjestu, opisujući etnokonfesionalnu sliku Like, Murgić kaže: (...) Ako bi jih tko upitao, koje su vjere, njemu bi odgovorili: jedan 'ja sam hrišćanin', a drugi 'ja sam katolik, najviše Hrvat', a Bunjevac kazao je, kako sam već naveo, vaviek 'ja sam pravi Bunjevac. Tako sam čuo u Liki odkad sama sebe pamtim, a toga ima više od pola vieka. (Ibid:4, 59) Spomenuti Murgićevi navodi predstavljaju vjerojatno posljednja izvorna svjedočanstva ličko-primorskih Bunjevaca o vlastitome tradicionalnom ("predmodernom") identitetu, a zbilo se to u trenutku kada je proces njihove integracije u hrvatski nacionalni korpus već znatno odmakao. Bunjevci su već tada i za autora navedenoga članka bili ništa drugo nego Hrvati. ${ }^{2}$ Te iste 1882. godine kada je Murgićev članak objavljen u Viencu, a koji je nastao na poticaj "ugarskog Bunjevca” naslovnoga biskupa Ivana Antunovića, u Beču je izdana knjiga navedenoga prelata pod nazivom Razprava o podunavskih i potisanskih Bunjevcih i Šokcih u pogledu narodnom, vjerskom, umnom, gradanskom i gospodarskom. U njoj se bunjevaštvo afirmira kao zasebna individualnost i to u kontekstu Strossmayerova jugoslavenstva kao ujedinjavajuće ideje. Premda je autor u toj političko-povijesnoj studiji isticao srodnost podunavskih Bunjevaca i Šokaca s Hrvatima i Srbima, jer svi su “jedne krvi i jednog jezika”, ipak je nedvosmisleno iskazao suzdržanost prema uporabi tih dvaju nacionalnih imena u bunjevačkoj sredini. ${ }^{3}$ Takva različita percepcija dvojice suvremenika sugerira nam da modernizacijske promjene u 19. stoljeću nisu zahvatile sve bunjevačke strukture istovremeno i podjednako. Dinamika povijesnoga razvoja, pa tako i ona nacionalnointegracijska, i nije mogla biti ujednačena u jednoj prostorno disperziranoj zajednici kao što je to bila bunjevačka, koja je živjela unutar različitih državnopolitičkih okvira i tradicija.

Bunjevački se predmoderni etnički sadržaj u 19. i 20. stoljeću transformirao u više oblika - kao integralni dio hrvatske nacije, kao hrvatska subetnija, a jednim manjim dijelom i kao zasebna etnonacionalna grupa. Razloge takvoga diferenciranog razvoja, između ostaloga, treba tražiti u povijesnom razvoju prethodnih stoljeća, tj. naslijeđu ranoga novog vijeka. Upravo se stoga nameće pitanje karaktera bunjevačkoga

Pukovnik Ivan Murgić (umro 1881.), rodom Ličanin iz Perušića, za kojeg je Jovan Erdeljanović krivo pretpostavio da je i sam bio bunjevačkog porijekla, napisao je spomenuti članak koji je 1882. posthumno objavljen u časopisu Vienac od broja 2 do 8 .

2 Osvrćući se na sličnosti u antroponimiji katoličkih Bunjevaca i pravoslavnih Vlaha u Lici, Murgić zaključuje: (...) pa zato mislim da neima dvojbe, da su oni samo jednoga naroda, nego i jednoga porekla, svi su Hrvati, svi su južni Slavjani, zvali se oni Bunjevci, Kranjci ili Vlasi. (Ibid.)

3 Antunović o tome govori u poglavljima: Srodnost Bunjevacah i Šokacahs Hrvatimi i Srbimi, po svem jugu rasprostranjenimi te Srodnost sudbine Bunjevacah i Šokacah s onom Srbina ugarskog. (Antunović 1882:50-55, 170). 
predmodernog ili prednacionalnog etniciteta kao društvene pojave, odnosno pitanja o kakvom se to tipu zajednice radilo, koja ih je to zajednička tradicija i interesi formirala kao grupu, odnosno, koji je bio fokus njihove grupne identifikacije. Nema sumnje da su Bunjevci već u ranome novom vijeku predstavljali zasebnu i prepoznatljivu zajednicu što je vidljivo i iz opisa suvremenika poput onih iz Vojne krajine, koji ih kvalificiraju kao "neobuzdan narod" (gente effrene), "ratoboran narod" (natio bellicosissima), "katoličko pleme" (katolische Stamm). U ovom ćemo se radu na razini problematizacije pozabaviti pitanjem oblikovanja i razvoja bunjevačkoga fenomena kao etničke i društvene pojave u ranome novom vijeku. Tako postavljeno istraživačko pitanje podrazumijeva analizu pojava, procesa i struktura koji su doveli do konstituiranja Bunjevaca kao zasebne i prepoznatljive etnokulturne i etnokonfesionalne grupe, te integracijsko/ dezintegracijske aspekte formiranja njihova predmodernoga, tradicionalnoga identiteta.

\section{HISTORIOGRAFSKI ZNAČAJ I METODOLOŠKI PRISTUPI}

$\mathrm{O}$ Bunjevcima u historiografiji postoji dosta obimna literatura, međutim taj fenomen još uvijek nije obrađen u cijelosti. Može se reći da bunjevačka "etno-historija” još nije rođena. ${ }^{4}$ Posebice nedostaju studije o ranonovovjekovnim aspektima njihova razvoja, kada se i pojavljuju kao prepoznatljiva zajednica. Vrlo je malo i radova koji obrađuju pitanje njihove uloge u artikulacijama ranonovovjekovnih identiteta. Nažalost, istraživanja fenomena identiteta i pripadnosti nerijetko su bila opterećivana modernim shvaćanjima, prije svega ideološko-političke naravi. Južnoslavenske historiografije nastale su u 19. stoljeću u tzv. "vijeku narodnosti", pa su od samoga početka najčešće bile zarobljenice romantičarskih mitova o naciji. Pritisak nacionalnoga političkoga imperativa nagnao je povjesničare da svojim djelima grade nacionalni identitet tražeći njegovo opravdanje u povijesnom kontinuitetu. ${ }^{5}$ Riječ je o povijesnoj svijesti koja je željela vidjeti povijest samo kao zrcalo svoje sadašnjosti, tj. koja je nastojala prekrojiti određene njezine trenutke prema legitimacijskim potrebama. (Gross 1996:382) U mreži takvih nacionalnoideologijskih aproprijacija našao se i bunjevački fenomen. Činjenica da se velika većina Bunjevaca tijekom 19. i 20. stoljeća potpuno integrirala u hrvatsku naciju utjecala je na neke krugove u hrvatskoj historiografiji da ignoriraju dinamične aspekte njihova povijesnog razvoja i današnje stanje projiciraju u prošlost, odlučno tvrdeći da Bunjevci oduvijek pripadaju hrvatskom narodu. Njihova interpretacija bunjevaštva, ali i općenito predmoderne (prednacionalne) hrvatske etničke zajednice, u osnovi je statična, retrospektivna i konačno pseudoznanstvena. Bunjevačka bliskost s nekim elementima srpskoga povijesnog naslijeđa (npr. štokavština, vlaško ime, dinarski kulturni krug) u srpskoj je historiografiji pak urodila stvaranjem konstrukcija o njihovu srpskom etničkom porijeklu (tzv. "katolički Srbi” ili pak "pokatoličeni Srbi”). Bunjevci su tako uključeni u ideologiziranu povijesnu shemu o srpskom ranonovovjekovlju kao dramatičnom razdoblju raseljavanja i rastakanja srpske etničke supstance od strane "srpstvu nesklonih" imperijalno-religijskih sklopova. Pojednostavljivanje i iskrivljavanje činjenica često su predstavljale temelj takvih argumentacija. Navedena zastranjivanja posljedica su dakako ideoloških redukcionizama i ograničenog pristupa povjesničara tim problemima. Sve je to dovodilo do nerazumijevanja temeljnih procesa i činjenice da je teško utvrditi prednacionalnu etničku sliku u smislu moderne definicije nacionalnoga bića. Drugim riječima, nije se shvaćala temeljna činjenica da su se i hrvatski i srpski moderni identiteti razvili iz mnogostranih, mnogoslojnih i mnogocentričnih predmodernih identiteta. Jedan je od njih bio i bunjevački.

Dosad korištene modele u istraživanju bunjevačkog fenomena konstruirali su najvećma etnolozi, antropolozi i lingvisti. Povijesna znanost ozbiljno zaostaje za tim disciplinama. O bunjevačkoj etnografskoj

Dosadašnje obrade bunjevačke teme u historiografiji bile su regionalno ograničene. Tako su primjerice radovi Petra Pekića bili ograničeni samo na bačke Bunjevce, a Dragutina Pavličevića na primorsko-ličke Bunjevce.

5 Još je Ernest Renan ustvrdio da je pogrešno poimanje vlastite povijesti dio bivanja nacijom. (prema: Hobsbawn 1993:14). 
baštini, običajima, pučkoj umjetnosti, narječju itd., danas već postoji ogromna znanstvena bibliografija. Pritom valja primijetiti da je fokus znanstvenoga interesa bio ponajviše usmjeren prema Bunjevcima u Podunavlju, dok su primjerice dalmatinski i posebice zapadnobosanski bunjevački ogranci ostali prilično neistraženi. ${ }^{6}$ Tek recentna istraživanja razvijaju uravnoteženiji prostorni pristup. ${ }^{7}$

Problemi etniciteta i identiteta i s njima povezana pitanja alterniteta i alijeniteta, asimilacije i akulturacije, interkulturne komunikacije i (in)tolerancije, stereotipa i predrasuda itd., jasno upućuju na kulturnopovijesnu dimenziju istraživanja bunjevačkoga fenomena. Inter-, trans- i multidisciplinarna suradnja kulturne povijesti tj. historijske antropologije i povijesnokulturne etnologije i antropologije nameće se tako kao metodološka nužnost. Ovdje treba pribrojiti i historijsku lingvistiku jer su jezici, narječja i govori također dio kulturne povijesti, tj. čimbenici identiteta koji u pravilu izravno ukazuju na porijeklo i razvoj neke etničke skupine. Uključivanjem tema, teorija, teza i metoda iz navedenih disciplina u povijesno istraživanje ili, drugim riječima, povijesnom kontekstualizacijom antropološke, etnološke i lingvističke problematike, kvalitetnije se može rasvijetliti etnokulturni razvoj Bunjevaca u povijesnim perspektivama. Primjerice, oblici zadružnog života Bunjevaca neobično su važni za razumijevanje sociodemografskih procesa, a ostaci povijesnokulturnoga naslijeđa poput tragova kulta predaka (krsno ime, $k r-$ sna slava), svadbenih običaja (npr. staćela) ili žetvenih običaja poznatih kao dužijanca, dožionica (Bačka), dožencija (Dalmacija) ili dožinjancija (Lika) mnogo pak govore o akulturacijskim tijekovima koji su zahvaćali bunjevačke zajednice. ${ }^{8}$ Navedeni primjeri govore u prilog "interdisciplinarnoj sintetizaciji”, međutim, treba biti svjestan i ograničenosti takvog pristupa. Naime, međudisciplinarni pristup pruža velike mogućnosti interpretacije i problematizacije, ali jednako tako postoji i opasnost od upadanja u zamku kvazipovijesnih i artificijelnih interpretacija kulturnih elemenata i njezinih izvora ili, kako je to Miroslav Bertoša naznačio, "etnografiranja” povijesti. (Bertoša 2002:303) Pri povijesnom istraživanju uvijek se susrećemo s osjetljivim pitanjem koliko npr. etnoantropološke spoznaje o pojedinim segmentima tradicijske kulture mogu biti čvrsto uporište za dalekosežne zaključke o složenoj i slojevitoj povijesnoj zbilji. Npr. teza Stjepana Pavičića da su Bunjevci dobili ime prema pastirskim nastambama bunjama ima svoje etnološko uporište, ali za povjesničara je to krajnje dvojbena teza s obzirom na povijesnu činjenicu da bunjevački fenomen izvire iz dinarskovlaških sociokonfesionalnih struktura, pa ostaje nejasno zašto bi te pastirske nastambe bile karakteristične samo za jedan dio vlaške populacije u Dinarskom gorju, i to onaj katolički. Interkulturalni fenomeni poput kulturnih dodira i transfera, miješanja i prožimanja, difuzije i migracije, nedvojbeno utječu na etnički razvoj, ali treba uvijek biti svjestan i činjenice da je kultura nadetnički fenomen, pa stoga kulturološka istraživanja ne mogu uvijek pružiti pouzdane pokazatelje za utvrđivanje etničkog porijekla neke skupine; ona to mogu samo u kombinaciji s drugim istraživanjima, prije svega povijesnim.

$6 \quad$ Iscrpnu bibliografiju o podunavskim Bunjevcima objavio je Ante Sekulić u svojoj znamenitoj studiji Narodni život i običaji bačkih Bunjevaca u Zborniku za narodni život i običaje, knj. 50, Zagreb, 1986, 459-470. Uvid u recentnu literaturu pruža i Leksikon podunavskih Hrvata - Bunjevaca i Šokaca koji izlazi serijalno, konkretno za same Bunjevce, u 4. svesku, Subotica, 2005, 19-72.

7 Etnološke komparativne studije dr. sc. Milane Černelić u: Bunjevačke studije. Zagreb, 2006.

8 Iz kulturne povijesti Bunjevaca posebno je zanimljivo pitanje porijekla i nastanka žetvenog običaja zvanog dužijanca, dožionica, dožencija, dožinjancija. Taj žetveni običaj kod podunavskih Bunjevaca (posebice subotičkih) poprimio je posebno svečan oblik, što i ne čudi s obzirom na ekohistorijske kontekste panonskih prostora. Međutim, ostaje otvoreno pitanje kada i pod kojim se uvjetima taj ratarski običaj pojavio u pastoralnoj kulturi bunjevačkih dinarskih stočara. Etimologija same riječi (izvedenica s pomoću lat. nastavka - antia i glagola dožeti) kao da simbolički odražava akulturacijska iskustva u prožimanjima starobalkanskih i južnoslavenskih etnojezičnih struktura. 


\section{BUNJEVCI KAO PREDMODERNA ETNIJA}

$\mathrm{P}$ itanje Bunjevaca kao predmoderne etnije nije moguće na zadovoljavajući način problematizirati ukoliko se prethodno ne analiziraju pojmovi predmoderna etnija i etnički identitet uopće. Svi ključni termini - etnicitet, etnija, etnos, ali i narod, nacija, nacionalnost - višeznačni su i u znanstvenom smislu neprecizni. Dosadašnji pokušaji teorijskog osmišljavanja pojma etniciteta urodili su nastankom ogromnog broja različitih stavova, pristupa, zaključaka i hipoteza. Neki teoretičari etniciteta poput francuskog sociologa Philippea Poutignata i etnologinje Jocelyne Streiff Fenart pokušali su to mnoštvo definicija i shvaćanja etniciteta sistematizirati u šest temeljnih kategorija. Prema njihovim istraživanjima etnicitet se može promatrati kao: 1) primordijalna činjenica, 2) proširenje srodstva, 3) izraz zajedničkih interesa, 4) odraz ekonomskih antagonizama, 5) kulturni sustav, 6) oblik društvene interakcije.(Putinja - Stref Fenar 1997:95-136) Očito da univerzalnu, općeprihvaćenu definiciju etniciteta nije moguće izvesti jer etnička identifikacija nikad nije samoobjašnjiva. ${ }^{9}$ Etničku grupu ili zajednicu čini kolektiv čije članove, sinkronijski i dijakronijski mogu povezivati: porijeklo, povijest, neki elementi kulture (npr. jezik, običaji, religija), teritorij, ekonomski interesi itd. Mogli bi stoga zaključiti da postoji onoliko definicija etniciteta koliko ima i etničkih skupina. Međutim, svim tim definicijama jedno je zajedničko: svi oblici etniciteta uvijek su rezultat nekog konkretnog povijesnog razvoja. Zbog toga je vrlo važno ispitati i povijesne dimenzije etničnosti, tj. fenomen predmodernih etničkih grupa.

Kad je riječ o fenomenima etniciteta i kolektivnog identiteta općenito, trebalo bi poći od pet temeljnih teorijskih pretpostavki:

1) svaki kolektivni identitet u pravilu se konstruira u relaciji spram Drugog, pa se tako i etnički identitet formira na osnovi dihotomizacije Mi/Oni. Etnicitet je stoga "Janus s dva lica" koji, u isti mah ističe jedno kolektivno "Ja" i poriče jednog kolektivnog "Drugog". (Ibid:137-138) Prema tome, etnicitet istodobno ljude i spaja (inkluzija, homogenizacija) i razdvaja (ekskluzija, separacija);

2) identiteti su konjukturni i varijabilni (Cliford 1988:11-12) stoga etnicitet predstavlja dinamičnu kategoriju budući da se definicije "nas" i "njih" neprestano preispituju i reinterpretiraju, ovisno već o društvenopovijesnoj i kulturnopovijesnoj dinamici;

3) svaki identitet u suštini je simboličkoga karaktera. Na simboličkoj osnovi zajednice komuniciraju i identificiraju se, stoga i etnicitet predstavlja "skup simbola", tj. pripada jednom od oblika simboličkog zajedništva;

4) svaki kolektivni identitet temelji se na osjećaju zajedničkoga iskustva, projekciji zajedničke prošlosti i budućnosti (porijekla i sudbine). Zbog toga etnicitet predstavlja društveni konstrukt, zamišljenu zajednicu (Anderson 1990:6-7), ali iako je zamišljena to ne znači da je i izmišljena zajednica; (Dženkins 2001:291)

5) ne postoji samo jedan identitet, oni su uvijek višestruki (multiply identitets). Postoje kolektivni i individualni identiteti; uz etnički i nacionalni supostoje i drugi oblici identiteta: staleški, klasni, vjerski, srodnički (klanski, tribalni), zavičajni, regionalni, rodni, strukovni itd. Ti identiteti mogu biti međusobno konvergentni ili divergentni što opet ovisi o povijesnim kontekstima.

Sa sličnim se problemom suočavamo pri određivanju pojma etniciteta i u društvima tradicijskoga tipa. Nema sumnje da se etnicitet može u najširem smislu odrediti kao jedna od temeljnih socioantropoloških kategorija. U svakom je društvu uvijek postojala stanovita "svijest o zajedništvu". Istražujući

9 U svojoj studiji Teorije o etnicitetu spomenuti autori prednost daju "minimalističkoj" definiciji norveškog sociologa Fredrika Bartha koja doduše ne pruža aprioran odgovor na pitanje porijekla i postojanosti etničkih grupa, ali ipak omogućuje da se identificiraju ključni problemi. Barthova definicija glasi: etnicitet je jedan oblik društvene organizacije zasnovan na kategorijalnom atributiranju kojim se ljudi razvrstavaju s obzirom na svoje pretpostavljeno porijeklo, oblik koji u društvenoj interakciji biva potvrden stavljanjem u opticaj socijalno diferencirajućih kulturnih znakova (Ibid.:159). 
problem etničnosti u prošlosti, sociolog i kulturni antropolog Emil Heršak iznosi najkraću moguću definiciju: etničnost je vrsta zajedništva, koja se prenosi i održava u transgeneracijskom hodu. (Heršak 1999:25) Prema istom autoru, istraživanje razmjera etničnosti u prošlim epohama mora u pravilu polaziti od posrednih pokazatelja, upozoravajući pritom da će se to istraživanje gotovo uvijek kretati na terenu hipoteza. (Ibid:25-26) Kod "predmoderne etnije" vrijedi zapravo sve ono što i kod problematike etniciteta uopće. Ponajprije je potrebno utvrditi u čemu se suštinski razlikuje od modernoga etniciteta tj. nacije u njezinom etnonacionalnom (srednjoeuropskom i istočnoeuropskom) značenju. S obzirom da koristimo pojam "predmoderan", znači li to da kroz poznatu sociohistorijsku distinktivnu shemu predmoderno/moderno i etnicitete razlikujemo prema tipu društvene organizacije. Znači li to da predmoderna etnija pripada "jednostavnom", "nerazvijenom", a moderni etnicitet "složenom", "razvijenom” tipu društvene organizacije? Ima li etničnost u tradicijskom društvu užu, a u modernom društvu širu osnovicu? Spadaju li, primjerice, srodstvo, religija i staleška pripadnost u tradicionalna područja identifikacije, dok su moderni etniciteti strukturirani po znatno složenijim i apstraktnijim kriterijima? Jesu li etniciteti prije 19. stoljeća samo fragmentirane sociostaleške zajednice ili postoje i neke druge integrativne spone? Drugim riječima, postavlja se pitanje koji su sve kriteriji vrednovanja jednoga predmodernoga identiteta: društvena i vjerska pripadnost, političko podaništvo i pokrajinsko porijeklo, jezik i običaji. Ta pitanja otvaraju za sobom i brojne druge istraživačke probleme, primjerice u kojem su suodnosu predmoderna etnija i ranonovovjekovni fenomeni kao što su etnokonfesionalizam, tribalizam, kampanilizam, banderijalizam, staleški patriotizam, plemićki i pučki protonacionalizam, politički narod i sl. Koje su zapravo razine predmodernih identiteta, postoje li uže i šire identifikacije, tj. višestruki aspekti identiteta, konačno u kojoj mjeri o predmodernoj etniji možemo govoriti kao o socioetničkoj, etnokulturnoj i protonacionalnoj zajednici.

Imajući na umu izloženo, istraživanje Bunjevaca kao tradicijske, predmoderne i prednacionalne zajednice mogli bismo započeti od šest ključnih pretpostavki, koje u priličnoj mjeri korigiraju i dopunjuju "šest zaključaka” koje je iznio srpski etnolog Jovan Erdeljanović u svojoj znamenitoj monografiji o Bunjevcima iz 1930. godine. ${ }^{10}$

a) Prije svega, riječ je o supralokalnoj tradicijskoj zajednici koja unatoč velikoj prostornoj disperziji dijeli zajedničko ime ("Bunjevac", "Bunijevac"), jezik (novoštokavsko ikavsko narječje), sjećanje (predaja o "pradomovini”), vjeru (katoličanstvo) i neke elemente dinarske kulturne tradicije (npr. model proširene obitelji, svadbeni običaji, divani i prela).

b) Bunjevački fenomen izvire iz vlaških sociokonfesionalnih struktura na imperijalnom trograničju u prvoj polovici 16. stoljeća. Bunjevački se identitet formirao na mjestima dodira s vlaškopravoslavnim elementom, tj. izgrađen je na dihotomijskom modelu bunjevci - rkaći. Bitna sastavnica tih identiteta jest pojava etnokonfesionalizma, odnosno procesa jačanja vjerskoga identiteta i konfesionalne kulture unutar vlaških društava, što je povezano s obnovom djelovanja srpske crkve (Pećka patrijaršija 1557.) i procesom katoličke obnove. Katolička crkva - prije svega Bosanska franjevačka provincija na osmanskom području i Senjska biskupija na habsburškom području - imala je značajan utjecaj u oblikovanju i razgraničenju bunjevačkoga etničkoga identiteta.

c) Bunjevački ranonovovjekovni identitet predstavljao je dinamičnu kategoriju; on se razvijao, širio i sužavao ovisno o povijesnim kontekstima prostora kojim su se kretali. Ta se dinamika identiteta ogledala

$\overline{10}$ Erdeljanović je svoje obimno istraživanje o Bunjevcima sveo u šest glavnih zaključaka: 1) da su primorsko-lički i podunavski Bunjevci porijeklom od dalmatinskih Bunjevaca; 2) da su se preci primorsko-ličkih i podunavskih Bunjevaca u masi iselili iz Dalmacije u vremenu oko 1622.; 3) da su preci svih Bunjevaca bili najvećim dijelom iseljenici iz zapadne Bosne i zapadne Hercegovine i iz susjednih krajeva srednje Bosne i donje Hercegovine; 4) da se svaka od ove tri grupe Bunjevaca poslije 1622. miješala s drugim etničkim elementima; 5) da se prema "istoriskim izvorima i kod svih pisaca iz prošlih vekova Bunjevci smatraju i nazivaju Srbima”; 6) da je naziv "Bunjevci” postao u Dalmaciji između 13. i 17. stoljeća. (Erdeljanović 1930:354-394) 
i u različitim percepcijama bunjevačkoga etnonima, od deprecijativnoga etnokonfesionalnoga nadimka (npr. Dalmacija) do legitimnoga pojma za jednu vjersku i etničku grupaciju (npr. Bačka).

d) Jezgru bunjevačkih skupina činili su katuni katoličkih Vlaha iz zapadne Hercegovine koji su doseljeni na širi prostor osmansko-mletačko-habsburške tromeđe u Hrvatskoj. Otuda proizlazi i temeljno proturječje prema kojem je bunjevački etnonim poznat u prostoru useljavanja, a nepoznat u ishodišnom području njegovih nositelja.

e) Seobe, ratovi, pobune i vjerske konverzije dinamični su čimbenici oblikovanja etničkoga identiteta Bunjevaca. Sociokulturni fenomeni granice također su utjecali na povijesni razvoj Bunjevaca koje stoga možemo smatrati i “krajinskom etnijom”. Seobe su ponajprije oblikovale bunjevačke identitete nejednakog intenziteta te podijelili bunjevačku zajednicu na četiri glavna ogranka: zapadnobosanski (osmanski), ${ }^{11}$ dalmatinski (mletački), ličko-primorski (habsburški) i podunavski (ugarski).

f) Bunjevački identitet bio je samo jedan od identiteta, supostojao je s drugim oblicima identiteta na sociostaleškoj razini (vlasi, morlaci, krajišnici), razini lokalnih zajednica (sela, knežinsko-plemenskih formacija, satnija i pukovnija u Vojnoj krajini), političkih podaništava i pokrajinske ("zemaljske") pripadnosti.

\section{PREDAJA O BUNI}

$\mathrm{P}$ oznata usmena predaja koja govori o porijeklu Bunjevaca od "Bune rike" u Hercegovini, nedvojbeno svjedoči o postojanju stanovite "zajedničke svijesti" među ranonovovjekovnom bunjevačkom populacijom. Predaja o zajedničkom porijeklu bila je svakako jedan od ključnih elementa u izgradnji predmoderne etničke zajednice Bunjevaca. Poznato je da mitovi i legende o prošlosti značajno sudjeluju u oblikovanju etnije i nacije. Britanski sociolog Anthony Smith tvrdi da "mitsko-simbolički sklopovi" imaju idejnu i praktičnu ulogu u izgradnji društvenih i kulturnih zajednica jer usmjeravaju kolektivne identitete, odnosno fiksiraju identitetske simbole koji izražavaju središnje vrijednosti neke zajednice i stvaraju osjećaj pripadnosti nekoj zajednici. (Smith 1988:15-26) Riječ je o pričama i uspomenama, stvarnim ili izmišljenim (ili pak "prerađenim") koje se obraćaju svijesti naroda uključujući njegove kulturne obrasce ili izražavajući duboke općeprihvaćene osjećaje. Fikcije o zajedničkim precima ili zajedničkoj pradomovini određuju etnicitet kao proširenje srodstva, kao "biološku" zajednicu, koja se može promatrati i kao jedna od varijanti klasičnih primordijalističkih teorija etniciteta. ${ }^{12}$

Prvi koji je - koliko je poznato - zabilježio legendu o porijeklu Bunjevaca s rijeke Bune, bio je čuveni padovanski redovnik Alberto Fortis koji o tome piše u dodatku engleskoga izdanja svoga djela Viaggio in Dalmatia (Travels into Dalmatia) izdanom u Londonu 1778. godine. Opisujući stanovnike primorskog dijela "Morlačke gore" (Velebita), u više navrata spominje Bunjevce za koje kaže: Stanovnici planina danas su posve različiti od onoga što su tada bili. Sami sebe nazivaju Bunjevcima, jer su došli s područja Bune u Bosni... (Fortis 1984:276-277) Istu legendu, samo s drugim regionalnim predznakom, spominje i fra Marijan Lanosović, tajnik franjevačke Kapistranske provincije, slavonski književnik i član carskog povjerenstva za izradu ilirskog pravopisa i gramatike. U Pridgovoru bogulyubnim shtiocem svog djela Evangyelistar Iliricski iz 1794. godine, pišući o jeziku i pravopisu između ostalog kaže: ...Bunyevac, tako nazvani od vode Bune u Dalmaciji, otkuda u Maxarsku doseli, svojim slavise, izuschenyem. (Lanosovics 1794:str. VI)

11 Kod zapadnobosanskih Bunjevaca treba razlikovati dvije skupine: "stariju” oko Livna, Kupresa i Glamoča i "noviju” na području Bosanskog Petrovca, Ključa i Sanskog Mosta. Noviju skupinu činili su zapravo lički Bunjevci koji su se nakon austro-ugarske okupacije Bosne i Hercegovine 1878. godine naselili pretežno u Krnjeušu i Kolunić (Bosanski Petrovac), Velagiće i Ramiće (Ključ) i Kljevce (Sanski Most). Mnoga od tih naselja uništena su i raseljena u Drugome svjetskom ratu, te u posljednjem ratu u BiH od 1992. do 1995.

12 Oblici "narod" i "porod" (lat. natio) za zajednicu "istorodnog” porijekla, govore u prilog primordijalističkog shvaćanja etniciteta. 
Lanosović je ovdje dakako mislio na podunavske Bunjevce. Legenda o Buni rijeci dalje je apostrofirana u prvoj polovici 19. stoljeća u djelima Julija Frasa (1835), Đorđe Brkića (1839), Đene Sarića (1842), Vuka Karadžića (1849), Manojla Sladovića (1856), Karla Coeringa (1857) i od tada postaje neizbježnim polazištem svake znanstveno-istraživačke obrade bunjevačke tematike. ${ }^{13}$ Postavlja se pitanje kako je uopće nastala ta legenda, radi li se tu o tek običnom pučkom etimologiziranju ili je ta neznatna rječica u epskoj kulturi Bunjevaca imala neku dublju simboliku.

Povijesni izvori osmanske provenijencije iz 15. stoljeća, kao i historijsko-lingvistička istraživanja, isključuju mogućnost da se na području uz rijeku Bunu (dužine $8 \mathrm{~km}$ ), ali i u širem Podveležju, mogla oblikovati etnička skupina iz koje bi potekli Bunjevci. Podaci iz osmanskoga poreznoga popisa (deftera) iz 1477. godine za sandžak Hercegovinu otkrivaju nam dobro poznate bunjevačke skupine (vlaški džemati Krmpota, Vojnića, Sladovića), ali na prostorima zapadno od rijeke Neretve. U nahiji Blagaj koja je obuhvaćala i područje Bune, između 36 tada popisanih vlaških džemata (katuna) teško da bi i jedan mogli izdvojiti kao bunjevački. Dapače, knežinska aglomeracija okupljena oko džemata vojvode Petra Hrabrena - znamenite vlaške obitelji iz Donjih Vlaha, ktitora nekih hercegovačkih manastira - upućuje na pomisao da je pretežit dio vlaške populacije na tom području bio pravoslavne vjere. ${ }^{14}$ Neretva je inače već u 15. stoljeću predstavljala prirodnu granicu ikavskoga i ijekavskoga novoštokavskoga idioma, pa je s obzirom na dosljednu ikavštinu u govoru Bunjevaca teško zamisliti da bi mogli potjecati s prostora istočno od rijeke.

Očigledno je da Bunjevci nisu došli s Bune rijeke, ali to ne znači da ne postoji poveznica tih dvaju pojmova, barem na simboličnoj razini. Vlaškim katunima u zapadnoj Hercegovini taj je hidronim i toponim sigurno bio dobro poznat jer se nalazio u njihovu komunikacijskom prostornom obuhvatu. ${ }^{15}$ Područje oko rijeke Bune smatralo se tradicionalnim središtem Humske zemlje. Iznad vrela Bune stoji stari grad Blagaj, gdje su nekoć boravili bosanski vladari, a potom i oblasni gospodari, Sandalj Hranić i njegov nasljednik herceg Stjepan Vukčić Kosača, po kojem je i Humska zemlja od 1448. poznata po svojem novom imenu Hercegovina. Franjevci provincije Bosne Srebrene u osmanskome razdoblju čuvali su tradicije vojvodstva u Hercegovini (herceštvo sv. Save) i općenito tradicije bosanskoga kraljevstva. Upravo je bosanskofranjevačka sredina mogla iznjedriti legendu, povezujući bunjevačko ime s imenom rijeke Bune kao simbolom Hercegovine, a sve iz vjerskopolitičkih motiva, odnosno pokušaja legitimiranja svojih pastoralno-jurisdikcijskih prava na granici prema dalmatinskim dijecezama. ${ }^{16}$ Bunjevci su tijekom 16. i 17. stoljeća pretežno živjeli u južnim i jugozapadnim područjima Kliškog i Ličkog (Krčkog) sandžaka koji su nominalno potpadali pod jurisdikciju dijeceza na dalmatinskoj obali ili pak rezidencijalnih biskupa, ali

13 Julije Fras je kod ličko-primorskih Bunjevaca zabilježio tradiciju o hercegovačkom porijeklu (I tzv. bunjevačke obitelji - katolicko pleme koje vodi podrijetlo iz Hercegovine - dobile su 1691. posjede u višs mjesta, kao: Sv. Mihovil, Sv. Rok, Vratnik, Ričice, Kosinj itd., u kojima se i danas nalaze.) Fra Grgur Čevapović tvrdi da su Bunjevci u Ugarsku došli iz Bosne i Dalmacije (e Dalmatia Bosnia coloniis exitis, horsumve traductis). Đorđe Brkić tvrdi da su se Bunjevci naseljeni u Budimu i njegovoj okolici doselili iz grada Bunje, koji se prostirao na granici Bosne i Srbije. Đeno Sarić zapisao je pak da je stara postojbina Bunjevaca bila pored obala rijeke Bune, koja odvaja Bosnu od Dalmacije. Vuk St. Karadžić piše: Bunjevci može biti da se zovu od Hercegovačke rijeke Bune, od koje su se, kao što se pripovijeda, negda amo doselili... Austrijski etnograf K. v. Coernig potvrđuje za ličke Bunjevce da su se doselili iz Hercegovine (Bunievische Familie, welche aus Herzegovina stammte), a za druge bunjevačke skupine kaže da su naselili krajeve oko Subotice.

14 O vlaškim skupinama na tom području usp. u: Aličić 1985:130-131.

15 Krmpotska zimišta Buhovo i Borajna (na krajnjem istočnom rubu današnje Bekije) bila su udaljena oko 22 km zračne linije od mjesta Bune. Selo Vojnići kod Ljubuškog koje je nastalo teritorijalizacijom katuna Vlaha Vojnića (1477. "džemat Vukašina sina Vojihne") udaljeno je od Bune oko 35 km zračne linije. Usp. Aličić 1985:84, 90.

16 Već je Krunoslav Draganović zapazio simboličku vrijednost rijeke Bune. Opisujući bunjevački etnički element na Kupresu, Draganović je primijetio: Ako Bunjevci doista potječu starinom iz Hercegovine, čemu se i Erdeljanović priklanja $i$ što za sebe ima jake razloge, onda doći "s Bune" koja izvre ispod nekad glavnog grada Hercegovine tvrdog Blagaja, znači isto što i reći, od Blagaja ili, zapravo, iz Hercegovine kada je bio, po poznatoj staroj riječi "Blagaj šeher, a kasaba Mostar". (Džaja-Draganović, 1994:407) 
su stvarnu brigu o tamošnjim katoličkim vjernicima preuzeli bosanski franjevci. U duhu katoličke (posttridentske) obnove, u drugoj polovici 16. stoljeća dalmatinski su biskupi počeli obnavljati svoj utjecaj u "nevjerničkom" osmanskom zaleđu (in patribus infidelium) što će na više razina dovesti do ogorčenih sukoba s bosanskim franjevacima oko pitanja pastolarno-jurisdikcijskih prava. Franjevci su kroz konstrukciju o Buni rijeci naglašavali hercegovačko porijeklo svoga vjerničkoga puka, a time i svoja prava na pastoralnu službu. Premda su samo bunjevačko ime doživljavali kao deprecijativno te ga, kao i vlaško ime, izbjegavali koristiti jer je "nedovoljno katoličko" ili čak "manje vrijedno", ipak su se tom legendom prije svega obraćali Bunjevcima kako bi ih jače vezali uz sebe (visovački samostan) i ograničili utjecaj svjetovnoga svećenstva (tzv. "glagoljaši”, "jeronimovci”, "ilirski kler”), a preko njih i dalmatinskih biskupa, o kojima nisu imali visoko mišljenje. ${ }^{17}$ Temeljna struktura toga konflikta - kako dobro primjećuje Srećko Džaja - nije bila borba za vjernike koliko borba za osiguranje materijalnih dobara i karijerizam sudionika. (Džaja 1999:191-201) Boreći se za prava svoje bosanske franjevačke provincije, bosanski povjesničar iz 18. stoljeća Filip Lastrić, na slikovit je način opisao suštinu toga sukoba, iznoseći tvrdnju da dalmatinskim biskupima nije stalo do spasa ovaca, nego se bore za njihovu vunu. (Zirdum 1982:86) U historiografiji je već skrenuta pozornost na Bunjevca fra Miju Radnića, vizitatora pokrajine Bosne Srebrene koji 1684. godine herceštvom svetog Save imenuje prostor od Gacka u današnjoj istočnoj Hercegovini do Gračaca u Lici. (Roksandić 1991:32) Roksandić taj Radnićev "panhercegovizam” tumači kao stanje svijesti stvoreno dugotrajnim seobama u čitavom tom prostoru koji se zbog toga i promatra kao jedinstvena "morlačka" cjelina. (Ibid.) Međutim, Radnićev stav možemo tumačiti i kao pokušaj prostornog legitimiranja njegove bosanske provincije u trenutku kad je već postalo jasno da je Osmansko Carstvo počelo uzmicati i da će pomicanje imperijalnih granica za sobom neminovno povući i pitanje eklezijalnog uređenja, a to je značilo i nove "bosansko-dalmatinske" crkvene zapletaje do kojih će uskoro i doći.

\section{PORIJEKLO BUNJEVAČKOGA IMENA}

$\mathrm{I}^{\mathrm{m}}$ mena često nose neka davno zaboravljena značenja (nomen est omen). Brojni pojmovi kojima se danas služimo rezultat su duge i krivudave semantičke evolucije u kojoj se višestruko mijenjao njihov sadržaj i opseg. Stoga etimologijska objašnjenja koja se nude nikada nisu ni jednostavna ni jednoznačna. I filološko objašnjenje pojma Bunjevac još je uvijek nesigurno. O porijeklu bunjevačkoga imena u literaturi postoji mnoštvo različitih mišljenja, pojedina imaju svoja znanstvena utemeljenja dok druga ne prelaze razinu pučkog etimologiziranja. Generalno ih možemo podijeliti na dvije skupine: jednu koja interpretira pučku predaju i ime izvodi od naziva hercegovačke rijeke Bune odnosno mjesta Bune na istoimenoj rijeci i od glagola buniti se; te drugu koju čine znanstvena, prije svega etnoantropološka i lingvistička mišljenja. Među njima ističu se tri teorije: jedna ime izvodi iz vlaškog antroponima Bun, druga iz kamene pastirske nastambe bunje, a treća iz pejorativno obojene imenice obonjavci. ${ }^{18}$

Svaka od spomenutih teorija ima svoja etnološka i lingvistička opravdanja. Za povijesno istraživanje potrebno je međutim utvrditi povijesnu dinamiku pojma: kada se po prvi put susreće, iz kojih sadržaja nastaje i kada eventualno prelazi u druge sadržaje. Drugim riječima, u bunjevačkom slučaju treba utvrditi kada i gdje je generički naziv pretvoren u etnonim. Činjenica je da se etnički identitet, pa tako i etničko nazivlje, nikada ne definiraju na endogen način tako da se prenosi etnička suština, već je on uvijek proizvod značenjskih akata druge skupine. Sociološki rečeno, egzogene i endogene percepcije i definicije nalaze se u odnosu dijalektičke suprotnosti.(Putinja - Stref Fenar 1997:161) U tom smislu i etnonimi najčešće

17 Među Bunjevcima djelovali su i neki utjecajni svjetovni svećenici koji su priznavali crkvenu vlast dalmatinskih biskupa. Npr. ninski prezbiter don Jure Matasović koji je često iz mletačkog Novigrada odlazio u vizitacije "nevjerničkih strana" ili čuveni don (pop) Stipan Sorić iz Gorice koji je 1638. bio u sporu s visovačkim franjevcima oko nadležnosti nad nekoliko sela u Ravnim Kotarima.

18 Opširan pregled svih teorija o porijeklu imena Bunjevac nalazi se u: Sekulić 1986:20-40. 
nastaju kao posljedica percepcije "drugih", a u bunjevačkom slučaju označitelji su bili srpskopravoslavni Vlasi. Međutim, da bi uopće razumjeli postanak etnonima, potrebno je najprije pokušati objasniti pojam Bunjevaca kao generičke imenice.

S obzirom na nedostatak povijesnih izvora koji bi pobliže rasvijetlili porijeklo i nastanak imena Bunjevac, istraživanje je potrebno započeti s historijskolingvističkom analizom samog pojma. Ona ne bi išla samo u prilog etimološkoj analizi fonetskih i semantičkih struktura nego bi trebala odrediti i društvenopovijesni sadržaj bunjevačkog imena, tj. nužna je njezina povijesna kontekstualizacija. Polazeći od osnovnih sociolingvističkih i historijskolingvističkih postulata prema kojima leksička struktura ne odražava samo društvenu organizaciju i interakciju već i povijesnu dinamiku, tj. prošlu zbilju, (Fischman 1978:23.24) porijeklo bunjevačkoga etnonima trebalo bi tražiti ponajprije u socijalnim ambijentima dinarskih Vlaha. Prema tome, mišljenja Đure Daničića, Petra Skoka i Milenka Filipovića koji su bunjevačko ime izvodili iz balkanskoromanskog antroponimijskog naslijeđa, time ponovo dobijaju na uvjerljivosti.

Leksička struktura etnonima "Bunjevac" ili "Bunijevac" ukazuje na patronimijski karakter pojma. Sastoji se od korijenske osnove bunj-i sufiksalne tvorbe - evac/-evci što jasno upućuje na posvojno i descedencijsko značenje imena. U tom smislu korijensku osnovu bunj-najprihvatljivije je izvoditi od vlaškoga antroponima Bun ili Bunj, tj. njegovih slaviziranih hipokorističnih izvedenica: Bunjo, Bunjak, Bunjac, Bunac, Bunoje, Bunilo, Bunislav. Struktura vlastito ime + sufiksalni segment -ovci/-evci karakteristična je upravo za dinarskovlaške sociotope. ${ }^{19}$ Nazivlje vlaških skupina najvećim je dijelom proisteklo iz vlaških biosocijalnih (agnatsko-patrijarhalnih) struktura. Vlaške skupine i njihovi katuni najčešće su dobivali imena prema svojim starješinama i rodonačelnicima tj. osnivačima katuna. Katun je predstavljao gentilnu zajednicu od više obitelji povezanih imenom, porijeklom, tradicijom i kulturom. Riječ je zapravo o bratstveničkoj zajednici koja se sastojala od više "obiteljskih zadruga" ili njihovih ostataka koje u cjelinu povezuje predaja da svi zajedno potječu od istog pretka, po kome se i nazivaju. Takav onomastički i toponimijski oblik naročito je u uzletu na području Hrvatske u 16. stoljeću, što je bila posljedica vlaških ranonovovjekovnih seoba i novoštokavskih impulsa koji su dolazili s jugoistoka. (Bjelanović 1987:178-179, 184)

Vlaški antroponim Bun/Bunj nastao je skraćivanjem od latinskog imena Bonifacius te promjenom vokala $o>u$ što je tipična fonetska pojava balkanskoga romaniteta. Glasovna promjena $n>n j$ rezultat je pak tzv. "novije jotacije" do koje dolazi tek poslije 14. stoljeća. ${ }^{20} \mathrm{U}$ srednjovjekovnim srpskim poveljama 13. i 14. stoljeća to se ime često susreće u vlaškoj sredini, pa i izvan nje (najstariji spomen u Žičkoj povelji iz 1220. godine). Međutim, prema kraju srednjega vijeka uočljiva je tendencija nestajanja antroponima Bun-Bunj. Izgleda da je to ime nestajalo usporedo s nestajanjem romanskog etnojezičnog karaktera vlaških skupina u Dinarskome gorju. Već u 15. stoljeću antroponim Bun i ostale njegove izvedenice u izvorima vrlo se rijetko susreću. Primjerice, u osmanskom poreznom popisu (defteru) u sandžaku Hercegovina iz 1477. godine gdje su pojedinačno evidentirana imena 7822 Vlaha kućedomaćina (uz koju udovicu) i još toliko imena njihovih očeva, to se ime javlja tek u dva navrata i to u slaviziranim oblicima: u nahiji Rudine u džematu Poblaha sina Radovana upisan je Bunjak sin Radovanov, a u nahiji Bjelopavlići spominje se stanoviti Bunušs sin Petra. (Aličić 1985:68, 102) Ogromnu većinu vlaških imena tada čine pretkršćanska ("slavenska") imena, najčešće s osnovama rad-, vuk-, drag-i mil-.

$\mathrm{Na}$ području srednjovjekovnoga Huma (Hercegovina) u 15. stoljeću nalazimo nekoliko vlaških skupina čiji glavari nose imena i prezimena izvedena iz osnove bun-. U istočnome Humu 1406. godine spominje se tako katun stanovitog Vlatka Bunislavića, a 1419. godine katun Vukote Bunčića što će reći sina ili potomka Bunovog. (Hrabak 1981:188) Na srednjovjekovnoj nekropoli u selu Bunčići, u području Radmilović-Dubrave kod Bileće, nalazi se visoki stećak čiji natpis spominje Bunca Rušovića. (Bešlagić

19 Npr. Vlasi Đuraševci, Vlasi Gleđevci, Vlasi Maleševci, Vlasi Tudoričevci itd.

20 Ta jezična promjena vremenski koincidira s pojavom novoštokavštine u području Hercegovine krajem 14. i u prvoj polovici 15. stoljeća, tj. s vremenom pojačane jezične asimilacije Vlaha. 
1971:390) Kako su stećke, posebice one većih dimenzija, podizale imućnije osobe, vjerojatno je riječ o grobu vlaškog starješine i to vjerojatno iz aglomeracije Vlaha Banjana. ${ }^{21}$

Kad je riječ o ostalim dinarskim oblastima u kojima se javljaju imena vlaških skupina s osnovom buntreba, pored spomenutih Vlaha Bunčića iz Bilećkih Rudina, istaknuti još dvije grupacije iz 14. stoljeća $s$ područja srednjovjekovne Srbije: vlaški rod Bunovića iz katuna Tudoričevci na Dečanskom vlastelinstvu te Vlahe Bunuševce iz okolice Vranja.

U Dečanskoj povelji (hrisovulji) iz 1330. godine, u kojoj je srpski vladar Stefan Uroš III. priložio novoosnovanom manastiru Dečani, osim sela i nekoliko "ubogih vlaških i arbanaških katuna”, spominje se i vlaški katun Tudoričevci. Katun se sastojao od 29 ognjišta, a Bunovići su predstavljali jednu od pet važnijih obitelji koje su imale proširen ("zadružan”) karakter. ${ }^{22}$ Ljetni pašnjaci nalazili su im se negdje na Visitoru kod Dobre Rijeke i Andrijevice, a zimišta u "altinskoj zemlji” u okolici Dečana. ${ }^{23}$ Inače, u istoj povelji spominje se i selo Bunjane kod Đakovice koje je brojalo 62 kuće, a nastavalo ga je zemljoradničko (srpsko) stanovništvo. ${ }^{24}$ Područje dečanskog vlastelinstva (koje je obuhvaćalo područje današnje Metohije na Kosovu, najsjeverniji dio Albanije te gornje Polimlje) zanimljivo je i zbog činjenice da je ono izvorište brojnih vlaških katuna, poput Mirilovića, Pilatovaca i Žurovića koji su se u kasnome srednjem vijeku i ranome novom vijeku selili prema sjeverozapadu. U vlaškim seobama 15. i 16. stoljeća Žurovići su stigli u istočnu Hercegovinu, Mirilovići su doprli do šibenskog zaleđa, a Pilatovci čak do Žumberka. ${ }^{25}$

Vlasi Bunuševci živjeli su u 14. stoljeću na području Vranjskog krajišta, tada osjetljivoj pograničnoj oblasti na istoku srpske države. ${ }^{26}$ Kao i ostali tamošnji vlaški katuni obnašali su vojničku službu čuvara granice, a podčinjeni su bili "krajiškom vlastelinu”. (Blagojević 1989:33-36) Nemoguće je ustanoviti što se točno dogodilo $s$ tom vlaškom skupinom u vrijeme osmanskih prodora i raspada Vranjskog krajišta krajem 14. stoljeća. ${ }^{27}$ Jedini podsjetnik na njih jest antroponim Bunuševac i selo Bunuša koje se nalazi južno od Leskovca, a nastalo je vjerojatno teritorijalizacijom njihova katuna. Povijesni izvori inače potvrđuju vlaške migracije iz okolice Vranja prema zapadu. Takav je npr. bio slučaj s čuvenim Vlasima Psoderima koji se spominju još 1345. godine u povelji kralja Stefana Dušana, kada su oslobođeni rabote na posjedu crkve sv. Nikole u Vranju koji je tada darovan manastiru Hilandar. (Ibid.:34) Ta se vlaška grupacija preko Kosova i Zete u više etapa iseljavala na područje Huma gdje se prvi put spominju već 1366 . godine. ${ }^{28}$ Seobu Vlaha Psodera valja promatrati u kontekstu krize feudalnoga sustava u Srbiji nakon smrti cara Stefana Dušana, ali i politike bosanskog bana, a potom i kralja Tvrtka I. koji je poticao doseljavanje vlaških "stočara-ratnika” iz srpskih oblasti. Jesu li Vlasi Bunuševci slijedili primjer svojih susjeda Psoderaca nemoguće je zasad ustanoviti jer izvora o tome nema. U Humu se doduše 1402. godine spominje katun Punoševaca ili Punoševića (Hrabak 1997:145) koji imenom podsjećaju na Bunuševce. ${ }^{29}$

21 Rušovići se u dubrovačkim izvorima spominju kao starješine jednog katuna u aglomeraciji Vlaha Banjana.

22 U povelji poimence se spominju: Bun i sin mu Nikola i Tvrtko i Tvrde i Tudorica, brat Rade i sin mu Vojisil (Ivanović 1951-1952:260).

23 Na nekadašnje vlaško bratstvo Bunovića podsjeća i današnja mikrotoponimija toga prostora. Po svoj prilici Bunova livada, (alb. Livadhi i Bon’s) u selu Shaptej kod Dečana stoji u vezi s tudoričevskim Bunovićima. Ime pak sela Shaptej možda je nastalo od rum. şapte "sedam", odnosno od "vlahiziranog" latinskog osobnog imena Septimus (Gashi:1982, 53).

24 Onomastičku građu iz Dečanske povelje gotovo do sitnih topografskih podrobnosti obradio je Mitar Pešikan u svojoj studiji Iz istorijske toponimije Podrimlja, I-III.

25 Mirlović Polje kod Drniša i Mirlović Zagora u zaleđu Šibenika, selo Pilatovci na Žumberku.

26 Vranjsko krajište obuhvaćalo je područje srednjovjekovnih župa u gornjem porječju Južne Morave: Vranja, Inogošta, Preševa, Dubočnice i Znepolja.

27 Smatra se da je do raspada vranjskog krajišta došlo nakon raspada Srpskog Carstva i pogibije gospodina Konstantina na Rovinama 1395. godine (Ibid.:35).

28 Katun Miloša Psodera (Hrabak 1981:186).

29 Kod Đakovice u Metohiji postoji selo Ponoševac (alb. Punashec) koji se u povijesnim izvorima nazivalo i Bonošući i za koje albanski lingvist Skender Gashi smatra da je sličnog postanja kao i ime vlaškog katuna Bunuševci iz okolice Vranja, tj. izvodi ga iz vlaškog oblika romanskog imena Bon (Gashi 1982:53). 
Historijskolingvistička i uopće kulturnopovijesna argumentacija govore u prilog tvrdnji da je ime Bunjevci prvotno označavalo pripadnike nekog vlaškog katuna. Ta tvrdnja doduše zasad nema potvrde u povijesnim izvorima osim u iznesenim analogijama (Bunčići, Bunovići, Bunuševci). U svakom slučaju, "vlahološki" usmjereni medijevisti i novovjekovci morat će uložiti još mnogo napora i truda da riješe ovu "dinarsku zagonetku".

\section{BUNJEVCI U SUSTAVU VLAŠKIH IDIOLEKATA}

U poraba etnonima Bunjevac gotovo da stoljećima nije izlazila izvan okvira tradicijske (oralne) komunikacije. Do druge polovice 19. stoljeća to ime praktički i nije bilo u službenoj i javnoj uporabi, tako da se u povijesnim izvorima susreće vrlo rijetko, uglavnom u pojedinim izvorima crkvene provenijencije. ${ }^{30}$ Pojam se najprije pojavio i koristio u komunikacijskom krugu vlaških društava na Tromeđi. Bunjevački je pojam stoga pripadao nekoj vrsti vlaškog idiolekta (etno-idiolekt), tj. vrsti žargona ili osobnoj varijanti jezičnoga sustava vlaške zajednice. ${ }^{31}$

Prvotno, (generičko) značenje imena Bunjevac vjerojatno je imalo, kao što smo mogli vidjeti, socijalnu atribuciju (pripadnik katuna Bunjevci). Istraživački ostaje otvoreno pitanje kada, gdje i kako je došlo do promjene semantičkoga sadržaja, odnosno do konfesionalizacije bunjevačkoga imena. Isto vrijedi i za njegov pravoslavni pandan, u riječi $R k a c ́$, čije je porijeklo također nejasno. ${ }^{32}$ Filološka analiza trebala bi ukazivati na povijesni okvir, tj. na mjesto, vrijeme i okolnosti pod kojima je došlo do te promjene. Prema svemu sudeći, prijelaz bunjevačkoga imena iz generičkoga naziva u etnonim dogodio se na osmanskom krajištu u kliško-ličkom prostoru ("oko Dinare i Velebita") sredinom 16. stoljeća, a može se razumjeti samo u kontekstu procesa etnokonfesionalinizacije vlaških društava. ${ }^{33}$ Naime, sve do sredine 16 . stoljeća vjerski je identitet u vlaškim zajednicama bio tek od sekundarnog značaja u odnosu na srodničke (katunske, "plemenske") i staleške identitete. U njihovoj patrijarhalno-pastoralnoj kulturi, ideologija srodstva i kult predaka predstavljali su na neki način surogat religije. Tome je razlog i taj što je utjecaj etabliranih religija u prostoru dinarskih planina uvijek bio slab i ograničen. Do prekretnice je došlo u 16. stoljeću kada religijske (i civilizacijske) konotacije imperijalnih sučeljavanja te obnova djelatnosti srpske crkve i katolička obnova dovode do jačanja konfesionalne kulture i identiteta na uštrb stare tradicije. Takav duhovnopovijesni razvoj vodio je prema vjerskim podjelama, otuđenju i nesnošljivosti unutar vlaških zajednica. Fenomen etnokonfesionalizma (spajanja etničkog i konfesionalnog tj. religijskog identiteta) naročito je bio izražen na prostorima pod jurisdikcijom Pećke patrijaršije gdje se srpstvo sve više poistovjećivalo $s$ pravoslavljem i obrnuto (fide serviana). ${ }^{34}$ Time je, posredovanjem Crkve, akulturacija Vlaha u srpski etnokulturni krug

30 Mađarski povjesničar István Iványi tvrdio je da se naziv "Bunjevci" kod podunavskih Bunjevaca nije pojavljivao u književnosti i javnom životu, zato što se bunjevačka inteligencija stidjela toga imena, koje se smatralo manje vrijednim, "seljačkim", te se je stoga nazivala "Dalmatincima”. Ipak, kaže Iványi, u narodu se bunjevačko ime uvijek upotrebljavalo. (Ivány, István. Szabadka szabad királyi város története. II, Subotica, 1892:579; usp. Erdeljanović 1930:294-295)

31 Definicija idiolekta u: Simeon, Rikard. Enciklopedijski rječnik lingvističkih naziva. sv. I. Zagreb, 1969, 506. Naravno, trebalo bi s teorijske strane propitati je li taj strogo lingvistički pojam primjenjiv i u kulturnoj antropologiji tj. historijsko-antropološkim istraživanjima.

32 Etnologinja Jasna Andrić u svojoj je studiji o Rkaćima (Rkačima) analizirala nekoliko mogućih etimologijskih objašnjenja te pomalo zagonetne riječi koja se javlja u više oblika (Rkać, Rkač, Arkač, Hrkać). Prvo i najstarije mišljenje povezuje ju s imenom Grk odnosno Grkać u značenju pravoslavac; drugi je izvode iz pridjeva rkovit (snažan, silovit) pa bi Rkaći bili isto što i "snažni, siloviti, naprasiti ljudi", treći od glagola "hrkati" (radi crkvenog pjevanja kroz nos), a četvrti je povezuju s dijelovima odjeće, tj. istočnjačkim ogrtačem (hrka). (Andrić 1988:43-58)

33 Općenito uzevši, možemo prihvatiti tvrdnje Jovana Erdeljanovića da je bunjevačko ime "nastalo" u Dalmaciji i Stjepana Pavičića da se bunjevačka "pradomovina" nalazila na području oko Dinare i Svilaje, naravno uz nužnu vremensku korekciju.

34 Sukladno tome, pećki patrijarsi nisu bili samo vjerske i duhovne starješine već i etnarsi, vođe naroda u političkom smislu. 
bila ubrzana i učinkovita. Zbog svog univerzalizma, "partikularni” etnokonfesionalizam nije bio izravno prisutan u Katoličkoj crkvi. Međutim, neizravna posljedica djelovanja u duhu posttridentrske katoličke obnove bila je također duhovnokulturna homogenizacija katoličkih zajednica, što je za vlaška društva u konačnici značilo podvajanje po vjerskoj osnovi (bifurkaciju). U 17. su stoljeću etnokonfesionalni identiteti u Vlaha na Tromeđi (srpskopravoslavni i katoličko-bunjevački) već bili čvrsto etablirani i antagonizirani. ${ }^{35}$

Vjerske podjele i nesnošljivosti unutar vlaških društava na Tromeđi oko 1550. oblikovale su konfesionalno opozicionirane grupe: vlaškopravoslavnu ("rkačka”) i vlaškokatoličku (bunjevačka). Taj je dihotomijski model u komunikaciji imao dvije leksičke razine: krstjani - ristjani i bunjevci - rkaći. ${ }^{36}$ Prvi je bio korektan, "prijateljski”, a drugi je služio, kako bi se izrazio Vladimir Ardalić, "za podruganiju”. Naime, pojmovi "bunjevac" i "rkač" tada dobivaju svoje novo deprecijativno značenje "etnokonfesionalnih nadimaka”, kojim se u odnosu prema vjerski "Drugom” željelo podrugljivo osporiti njegova kršćanska bit, tj. "opoganiti ga”. ${ }^{37}$ Nekako u isto vrijeme svoje deprecijativno značenje zaokružuju i ostali etnokonfesionalni "nadimci” na širem osmanskom području: poturi, balije, šokci. Poznati pejorativni naziv za muslimansko seljačko stanovništvo u Bosni i Hercegovini - balije - u početku se odnosio samo na muslimanske sezonske stočare vlaškog porijekla iz središnjih dijelova Hercegovine, koji su oko 1530. masovno prelazili na islam..$^{38}$ Etnonim Šokac, uz neke izuzetke, uglavnom ne interferira s katoličkovlaškim prostorima na jugu; to se ime odnosilo ponajprije na agrarne katoličke zajednice u Bosni i Slavoniji. ${ }^{39}$ Ovdje treba upozoriti da na širem prostoru Tromeđe u 16. stoljeću nisu sve vlaškokatoličke skupine bile hercegovačkoga porijekla, stoga nisu ni svi katolički Vlasi bili Bunjevci. ${ }^{40}$

Pored utjecaja crkvenih (etnokonfesionalizam) i državnih struktura (krajiški mentaliteti), vjerske podjele i suprotnosti u vlaškim društvima ne mogu se sasvim objasniti i razumjeti bez uvida i u neke soci-

35 Jedan od ranih primjera takvih konfesionalnih "grčko-rimskih" antagonizama nalazimo kod vlaško-crnogorskih doseljenika u Mletačkoj Istri 1622. godine. Te je godine pop Jovan iz Mrkojevića kod Bara (Skadarski sandžak) u istarsko selo Jural (Limska draga) na području Dvigrada doveo grupu od 14 crnogorskih pravoslavnih obitelji koji su investiturom preuzeli tamošnje zapušteno i neobrađeno zemljište. S njima su tada kao izbjeglice pred Turcima doselili i katolici (12 obitelji) koje je predvodio fra Franjo Poruba. Međutim, katoličke obitelji odvojile su se od popa Jovana i odbile se naseliti povrh Limske drage, a u svojoj žalbi rašporskom kapetanu Contariniju kao glavni razlog neslaganja istakli su da "oni žive po latinskom obredu, a ostali po grčkom i da se zato ne bi nikada mogli slagati" (asserendo di uiuer essi sotto il rito latino, et gli altri sotto il Greco; onde non stariano mai bene insieme). (Bertoša 1986:169) Najslikovitiji opis etnokonfesionalnih podjela ali općenito i stupnja religioznosti u vlaškim društvima na Tromeđi 17. stoljeća dao je 1692. godine generalni providur Mletačke Dalmacije i Albanije, Alessandro Molin koji je primijetio: Taj pomiješani svijet razdijeljen je u dva obreda, latinski i grčki, ali je to kod njih neka treća vrst tužne kvalitete, oni su naime tako slijepi u vjerovanju, da im daje ime kršćana samo to što nisu obrezani, oni su slijepi za svaku vrstu prave vjere. (Novak 1971:599)

36 U govornom se jeziku nikako ili vrlo rijetko koristila knjiška, "učena” terminologija kojom se negativno apostrofiralo pripadnike pravoslavlja kao npr. grci, šizmatici,odmetnici, krivovirci (Džaja, 1999:108).

37 U svojoj Razpravi Ivan Antunović navodi podatak koji je čuo od dalmatinskog franjevca Antonija Zorice 1880. godine, da je kod dalmatinskoga Bunjevca i Srbina navada, ako se pririeče, da Bunjevac dovikuje Srbinu ti si Hrkač, a ovaj mu odvrati ti si Bunjevac, što bi po priliki veli značilo: kao da bi se tim osnaživalo poganstvo. (Antunović 1882:52-54)

38 Balija je značio "šarenog” muslimana, onoga koji prakticira tajno dvovjerstvo, pa je taj pojam sinonimičan s alb. "ljaraman” (šaren) koji također označava "muslimana kriptokršćana”. Korijen bal- etimolozi dovode u vezu sa starobalkanskom riječju (ilirsko-tračkom) koja označava nekoga koji ima "bijele pjege”, tj. koji je šaren (Skok, Petar. Etimologijski rječnik hrvatskog i srpskog jezika. I, 1971:102-104).

39 U selu Kijevu u Vrličkoj krajini zabilježena je zanimljiva pojava interferencije bunjevačkog i šokačkog imena. Naime, katolički i pravoslavni Kijevljani su prema vani bili poznati kao Bunjevci i Rkaći, međutim, unutar seoske komunikacije, katolički komšiluci nazivani su "šokačkim", a pravoslavni "kranjskim” imenom. (Čulinović Konstantinović 1989:109-182)

40 Npr. katolički Vlasi u donjem Pounju (Zrin, Novi) nisu bili Bunjevci već sociostatusno "valahizirani” hrvatski starosjedioci. Slično je i s tzv. osmanskim "Vlasima Istrije” koji su djelomice potjecali iz zajednica hrvatskih Vlaha i koji su se od 1520-ih do 1570-ih "kružno" selili u prostoru od zadarskog zaleđa i Podgorja ("Morlakije”) preko Like i Žumberka do Istre i Krasa. Ni uz ovu se grupaciju ne veže bunjevačko ime. 
opsihološke i socioantropološke fenomene (npr. narcizam malih razlika, mentalne barijere i sl.). Potreba zajednica, koje se nalaze u susjedstvu i koje u svakom drugom smislu stoje bliske jedna prema drugoj, da se međusobno razlikuju, uzajamno spore i mrze nije svojstvena samo vlaškoj sredini. Činjenica je da se kohezija grupe povećavala ako je grupa imala rivalitetnu grupu dovoljno sličnu i različitu da "cementira” interne granice. Te su razlike mogle biti u konfesionalnoj pripadnosti, u mentalitetu, načinu života, jeziku, kulturi i dr. Potenciranje i očuvanje takvih počesto malih i banalnih razlika postale su pitanjem očuvanja posebnosti identiteta grupe (npr. binarne opreke u vlaško-bunjevačkoj antroponimiji tipa ĐuroJure, Jovo-Ivo, Stevo-Stipe). Katolička i pravoslavna crkva na prostoru Tromeđe davale su glavni poticaj u uspostavljanju takvog sustava malih razlika među stanovništvom koje je u suštini dijelilo istu sociohistorijsku situaciju. (Roksandić 1988:134) Npr., uvođenjem novoga "gregorijanskog" kalendara, male vjerske razlike postale su prepoznatljive i na razini životne svakodnevice. Problematizirajući pitanje etnokonfesionalnih i protonacionalnih identiteta u vlaškim društvima, Roksandić je konstatirao: Vlaške zajednice u jugoistočnoj Evropi u ranom novom vijeku izmiješano su podijeljene između tri velike monoteističke vjerske zajednice (pravoslavna, katolička i islamska). Ta izmiješanost dijelom je posljedica učinka sukoba interesa država s kojima se svaka od monoteističkih religija identificira, a dijelom se održava i zato što je u skladu s instinktivnom, životnom potrebnom ljudi u dinarskom prostoru da se izoliraju jedni od drugih, da svoj strah jednih od drugih ili agresiju jednih prema drugima pravdaju razlozima koji prelaze granice njihove svakodnevnice. Takva vjerska ispremiješanost izraz je i unutrašnje potrebe $i$ Vlaha i njihovih zajednica da svoje mectusobne razlike legitimiraju i razlozima, legendarne, mitske, vjerske i moralne provenijencije. (Roksandić 2004:237)

U vlaškim društvima ranoga novog vijeka, pored vjerskih, postojale su podjele i po drugim kriterijima. Jedna od njih je i podjela prema etnojezičnom kriteriju koja je razlikovala slavenske od romanski govorećih Vlaha, tzv. Cíća koji su se nakon 17. stoljeća uspjeli održati još jedino u Istri. Tu su i podjele prema socijalnom položaju (carski, spahijski i vakufski Vlasi u Osmanskom Carstvu; krajiški i privatni Vlasi u Habsburškoj Monarhiji, Morlachi habitantni nuovi i Morlachi habitanti vecchi u Mletačkoj Republici), lokalnom, političko-regionalnom porijeklu itd. U krajevima istočne Hercegovine i Crne Gore gdje se razvila snažna plemenska organizacija, već je u 16. stoljeću sasvim nestalo vlaške socijalne atribucije, a podjele su postojale isključivo prema tribalnom obrascu.

Vlaškokatoličke, bunjevačke skupine od 1520-ih godina kontinuirano egzistiraju na prostoru Tromeđe, kako one "stare" oko Novigradskog mora tako i one "prave" kod Knina nakon Karlovačkog mira 1699. godine. Međutim, državni aparati triju imperijalnih sila rijetko kada su ih identificirali pod bunjevačkim imenom kao posebnu skupinu, odnosno nisu ih razlikovali od ostalih zajednica koje su potjecale iz vlaškoga društvenopovijesnoga miljea. Osmanska vlast ne pravi velike razlike među vlaškim zajednicama, pa tako ne ističe ni Bunjevce; oni su samo dio vlaškoga društvenoga reda (Eflakan ta’ifesi). Mletačka ih vlast kroz cijelo razdoblje ranoga novog vijeka prepoznaje samo kao katoličke Morlake (Morlachi del rito Latino), dok potvrda o bunjevačkom imenu u venecijanskom i dalmatinskim arhivima još uvijek nema. Habsburške vojnokrajiške vlasti također ističu katolički karakter pojedinih vlaških doseljenika, ali bunjevačko ime vrlo rijetko koriste. Bunjevačke doseljenike u prostoru Primorske krajine, a potom i Like i Krbave pored uobičajenih naziva, kao što su "uskok", "prebjeg”, nazivaju ih još katoličkim Vlasima (catholische Walahen), a ponekad i katoličkim Rašanima (Rasciani catholici). U Podunavlju, u 18. stoljeću, ugarska županijska vlast također ne upotrebljava bunjevački etnonim već ih prepoznaje kao Dalmatince i "katoličke Race".

Barokni polihistor J. W. Valvasor u svom čuvenom djelu Die Ehre des Herzgothmus Krain iz 1689. godine u kojem daje prvi sustavni etnografski opis kranjsko-hrvatskoga područja, Vlahe tretira kao cjelinu, tj. ne spominje subvlaške entitete pa tako ni Bunjevce. Opisujući Vlahe (Walachen) u Primorskoj krajini kaže da su dijelom rimokatoličke vjere i da su srodni susjednim "Morlacima" misleći na mletačke podanike. Njihov štokavski jezik naziva vlaškim (die Walachische Sprache) koji je uvelike blizak mit der Dalmatischen oder Schlavonischen Sprachen. (Roksandić 2003:188, 203) Istu paradigmu slijedi i zapovjednik Karlovačkoga generalata Johann Joseph grof von Rabatta. U svojim izvješćima i spisima, koji su nastali tijekom njegova zapovijedanja Karlovačkim generalatom od 1709. do 1730. godine, stanovništvo 
Hrvatske i Primorske krajine te Like i Krbave dijeli najprije prema "etnokulturnom ključu" u dvije etnije: Hrvate i Vlahe. Hrvatima je označavao stare habsburške podanike katolike, a to znači hrvatske starosjedioce u Krajini, te doseljenike iz provincijalne Hrvatske (Gornje Pokuplje, Vinodol) i Kranjske. Vlasima je pak nazivao sve nositelje patrijarhalno-pastoralne kulture dinarskog areala neovisno o vjerskoj pripadnosti, odnosno sve stanovništvo koje je potjecalo od starijih i novijih prebjega s osmanskoga i mletačkoga područja. Čak i bivši "lički Turci” koji su pokatoličeni potkraj 17. stoljeća u jednom se Rabattinom izvješću nazivaju novokrštenim Vlasima. (Lazanin 2002: 101-102, 127-128, 131-133) Rabata je dakako bio svjestan konfesionalnih razlika među Vlasima, ali to je za njega tek od sporednog značaja.

Tek od druge polovice 18. stoljeća, kada u ozračju prosvjetiteljstva i predromantizma raste etnografsko zanimanje za šire prostore Tromeđe, bunjevačko se ime naglo pojavljuje u literaturi. O Bunjevcima u Primorskoj Hrvatskoj prvi piše Alberto Fortis u dodatku engleskog izdanja svoga dijela (Viaggio in Dalmatia) Travels into Dalmatia izdanom u Londonu 1778. godine. Opisujući stanovnike primorskoga dijela "Morlačke gore" (tj. Velebita), u više navrata spominje Bunjevce: Stanovnici planina danas su posve različiti od onoga što su tada bili. Sami sebe nazivaju Bunjevcima, jer su došli s područja Bune u Bosni (...) Bunjevac se smatra sretnim ako ima zalihu krumpira za hranu (...) Bunjevci ili katolički Morlaci u tim krajevima imaju običaj natrpati mnogo meda u kovčege svojih mrtvaca...(Fortis 1984:276-277) Srpski prosvjetitelj Dositej Obradović nakon višegodišnjeg boravka u sjevernoj Dalmaciji u dijelu Совъти здрабаго разума iz 1784. godine spominje bunjevačko ime, i to kao izrazito interkonfesionalno relacioniran pojam: “...3a пость, ко пости Среду он э ркаћь а ко Суботу он э бунъваць.” (Erdeljanović 1930:286) To potvrđuje i u svojoj drugoj knjizi Езопове прочихъ разнихъ баснотвориевъ iz 1788. godine gdje kaže da oni u "našem narodu" koji su "grečeskoga zakona" zovu one koji su "rimskoga" zakona "ili šokci ili bunievci ili rimci ili latini. A ovi one, vlasi, rkaći i šizmatici. (Ibid.) J. M. Korabinszky u svom Geographischen-historisches und Produkten Lexicon von Ungarn iz 1786. godine piše da u Ugarskoj žive "Bunjevci zvani Dalmatinci”. (Ibid.:295) Slavonski književnik i član carskog povjerenstva za izradu ilirskog pravopisa i gramatike fra Marijan Lanosović u "Pridgovoru bogulyubnim shtiocem" svoga djela Evangyelistar Iliricski iz 1794. godine također spominje Bunjevce i njihovu seobu u Mađarsku od "vode Bune u Dalmaciji”. Balthazar Hacquet, francuski liječnik u austrijskoj službi u svojem djelu Abbildung und Beschreibung der südwest und östlicher Wenden, Illyrer und Slaven, koje je nastalo između 1802. i 1805. godine, spominje Bunjevce kao dio "ličkog naroda" (Likaner Volk). Prema njemu, Bunjevci se ističu svojim junaštvom, najhrabriji su od svih Ličana (koje naziva “austrijskim Crnogorcima”), poludivlji su, skloni pljački, a žene su im najkreposnije. (Hacquet 1802-1805:165, 177)

I unutar katoličkih eklezijalnih struktura različito se odnosilo prema bunjevačkom imenu. U bosanskofranjevačkim izvješćima, kronikama, književno-teološkim i povijesnim djelima bunjevačkom imenu nema ni traga. Čak ni čuveni podatak iz 1622. godine o "parohiji Bunjevci" u Podunavlju, ne donose franjevci nego svjetovni svećenik don Šimun Matković. Bosanski franjevci inače vrlo rijetko povezuju katoličku konfesionalnost s vlaškim imenom. Rijetke su njihove opaske o katoličkim Vlasima, kao ona makarskog biskupa fra Marijana Lišnjića koji se tijekom vizitacije 1670. i 1671. uspeo na planine Vitorog i Ljubušu, gdje je u ljetno doba našao pastire "Morlake" i njihova dušobrižnika fra Antu Ripčanina o kojima se loše izražava. (Jurišić 1972:58) Bosanski franjevci kao nositelji gotovo cjelokupnoga vjerskog i kulturnog života katolika pod osmanskom vlašću, koji su i sami potjecali iz tog naroda i živjeli s njim, itekako su bili svjesni socioetničkih i etnokulturnih razlika u svojoj pastvi, a koje su bile naslijeđene još iz medijevalnog razdoblja (agrarne i pastoralne zajednice, rudari i varošani). Držeći se strogo konfesionalnoga kriterija, bosanski franjevci nisu isticali te razlike, odnosno, svodili su ih na najmanju moguću mjeru. $U$ “ilirskim tekstovima” svoje su katoličke vjernike označavali samo kao krstjane, a u "dijačkim”, tj. latinskim i talijanskim tekstovima kao katolike i kršćane-katolike. S druge pak strane, vlaško je ime već početkom 17. stoljeća u bosanskoj provinciji ili barem u njezinom većem dijelu postalo sinonimom za pravoslavnoga kršćanina. Matija Divković u svom Nauku krstjanskom iz 1611. godine, identificirao je u sintagmi "krstiani i vlasi" katolike s kristiani, a srpskopravoslavne s vlasi bez pejorativne primjese. (Džaja 1999:108) 
Katoličke strukture iz dalmatinskih biskupija pod mletačkom vlašću također ne bilježe bunjevačko ime posebno već ih identificiraju pod zajedničkim "morlačkim" imenom (Morlachi chatolici, Morlachi christiani del rito Latino i sl.). Za razliku od bosanskih franjevaca, crkvena hijerarhija u Dalmaciji, vjerojatno pod utjecajem mletačke administrativne terminologije, ne krije već upravo potencira morlačko (vlaško) ime i njegove društvenopovijesne kontekste. ${ }^{41} \mathrm{U}$ mletačkoj terminologiji ranoga novog vijeka Morlak jest konfesionalno konotiran pojam, ali samo u relaciji spram Turčina tj. muslimana. Drugim riječima Morlak je bio sinonim za kršćanina obaju obreda, "latinskog" i "grčkog", koji je dolazio s osmanskog pograničnog područja. ${ }^{42}$ To je i razlog što će jedino u Dalmaciji vlaško ime sačuvati svoje šire sociokulturno značenje (Vlaji) i neće biti reducirano samo na srpskopravoslavnu sastavnicu kao što se to dogodilo u Bosni, Hrvatskoj i Slavoniji.

Senjsko-modruška biskupija u Hrvatskoj predstavlja izuzetak. To je jedina crkvena institucija u ranome novom vijeku koja je bunjevačko ime uvela u službenu uporabu, posebice u prvoj polovici 18. stoljeća u vrijeme biskupovanja Martina Brajkovića, Benedikta Bedekovića, Adama Ratkaja, Nikole Pohmajevića, Ivana Antona Benzonija i Juraja Vuka Čolića. Srpski povjesničar Vojin S. Dabić koji polazi od pretpostavke da su Bunjevci srpskog etničkog porijekla o toj pojavi zaključuje ovako: Izgleda da uvođenje u upotrebu novog imena za Vlahe katolike u vreme kada su počeli da se naseljavaju u Lici i Krbavi, gde su predstavljali izrazitu manjinu u odnosu na pravoslavno stanovništvo, nije bilo slučajno. Novim imenom želela je Rimokatolička crkva da potisne njihovo dotadašnje ime, pošto su pojmovi Vlah i vlaški postali tada čak i u zvaničnim spisima sinonimi za Srbin i srpski odnosno pravoslavni. (Dabić 2000:106) U ovoj tvrdnji ima istine, ali i pretjerivanja. Najprije, ne radi se o "novom imenu" već o starom terminu koji je preuzet iz pučke sredine i uveden u službeni diskurs Crkve, što kako smo vidjeli nije bio slučaj na drugim prostorima. Međutim, Dabić je sasvim u pravu kada tvrdi da je uklanjanje vlaškog imena bio prvi korak prema čvršćem integriranju bunjevačkih skupina u katolički kulturni krug na prostorima senjske Crkve. Senjska dijeceza obuhvaćala je oko 1700. godine područje četiriju kapetanija u Karlovačkom generalatu (Senj, Otočac, Ogulin i Tounj) te prostor Like i Krbave gdje je među vlaškom populacijom u velikoj većini dominirao srpskopravoslavni element. Zbog toga je u senjskoj Crkvi, kao i u susjednim dijecezama, zagrebačkoj i ljubljanskoj, vlaško ime tijekom 16. i 17. stoljeća postupno postalo sinonimom za pravoslavca ("šizmatika”) tj. pripadnika Srpskopravoslavne crkve. U skladu s takvom percepcijom, vlaško ime više nije moglo niti je smjelo funkcionirati unutar katoličke zajednice jer bi se time dovodilo u pitanje lojalnost i konfesionalni identitet. Stoga su svećenici u Senjsko-modruškoj biskupiji i posegnuli za pučkom tradicijom iz koje su izvukli bunjevačko ime koje im je poslužilo kao differentia specifica u odnosu na vlaške "šizmatike". Iz perspektive Senja, na bunjevačko se ime nije gledalo s podozrenjem kao u slučaju Visovca. Senjski biskup Martin Brajković 1702. godine koristi dvojni naziv "catholici Valachi alias Bunievczi" da bi u sljedećim godinama otpala vlaška, a ostala samo bunjevačka identifikacija. Vojni svećenik za cijelu Liku i Krbavu, Andrija Josip Mandal u svom izvješću iz 1733. godine Bunjevce ne naziva više Vlasima nego stanovništvom koje je odijevanjem, načinom života i običajima slično ("similia”) Vlasima. (Burić 2002:132) I u popisu Like i Krbave iz 1712. godine uočava se ista tendencija. Popisivači pod pojmom Vlasi (Valachi) isključivo podrazumijevaju pravoslavce dok su pod zajedničkim pojmom katolik objedinili različite katoličke etnokulturne grupacije koje se tada susreću na ličko-krbavskom prostoru pa tako i bunjevačku. ${ }^{43}$

$\overline{41}$ Takvu praksu slijedili su i svjetovni svećenici (ilirski kler) na mletačko-osmanskom pograničju u Dalmaciji. Npr. kapelan župe kliške, vranjicke i kamenske don Ivan Božinović, u jednoj se ćiriličnoj ispravi iz 1659. godine potpisuje kao kapelan vlaški. (Klaić 1899: sv. 5, 15)

42 Mile Bogović to ovako interpretira: U mletačkim spisima 17. i 18. stoljeća naziv Morlak upotrebljava se za sve kršćansko stanovništvo duž mletačko-turske granice, kao padan muslimanskom stanovništvu s one strane $i$ stanovništvu primorskih gradova sove strane granice. (Bogović 1993:16)

43 Katoličko svećenstvo predvođeno Markom Mesićem posredovalo je kod popisivanja stanovništva 1712 . U većinski bunjevačkim naseljima Lovincu, Novom, Smiljanu i Pazarištu župnicima su 1712. bili: Damjan Zdunić (pop Zduna iz narodne predaje), Petar Butković, Šimun Zdunić i Juraj Smolčić. 
Međutim, nije se radilo samo o imenu već i o širim aspektima sociokulturnoga identiteta. Katolički su Vlasi tj. Bunjevci doseljavanjem na područje pod jurisdikcijom senjskih biskupa jasno svojom pojavom ukazivali da se radi o katolicima s drukčijom tradicijom. Njihova tradicijska, pastoralno-patrijarhalna kultura bila je upadljivo zajednička s tradicijama "šizmatičkih" Vlaha tj. jasno je podsjećala na njihove zajedničke "dinarske", odnosno hercegovačke korijene. S druge strane, Bunjevci su se jezikom, antroponimijom, odijevanjem, načinom prehrane, načinom života, mentalitetom, običajima itd., u značajnoj mjeri razlikovali od ostalih katolika na tom prostoru (Hrvati, Kranjci). Senjsko-modruški biskupi su tijekom čitavoga 18. stoljeća nastojali nizom mjera potaknuti akulturaciju i integraciju Bunjevaca u "senjski kulturni krug” te izbrisati razlike između njih i ostalih katoličkih zajednica. Organiziranjem naselja prema konfesionalnoj osnovi i formiranjem novih župa, akulturacijski tijekovi, spontani i prisilni, dobivali su na intenzitetu. U tome su Katoličku crkvu uvelike pomagale i vojnokrajiške vlasti. Tako su se krajem 17. i u 18. stoljeću u Lici ali i šire, u velikom broju sela Bunjevci našli pomiješani s drugim katolicima. Tijekovi akulturacije bili su dvosmjerni, Bunjevci su obično na Hrvate i Kranjce prenosili svoju štokavštinu, ali su s druge strane usvajali nove kulturne obrasce i postajali "Hrvatima", "Kranjcima" i sl. Samo još prezimena u nekim "miješanim" ličkim i kordunskim selima otkrivaju bunjevačke tragove. ${ }^{44}$ Jedan od primjera uspješne akulturacije su i promjene u bunjevačkoj antroponimiji. Npr. oko 1700. godine pretkršćanska (slavenska) imena poput Miloš, Radovan, Stojan, Vuk bila su uobičajena među Bunjevcima. Prema popisu iz 1712. godine izgleda da je od "narodskih" imena među Bunjevcima naročito bio popularan hipokoristik Vule, Vuleta. Međutim, jedno stoljeće kasnije ta su imena gotovo sasvim nestala u bunjevačkoj sredini i od tada se na području Like i Primorja imena takvog tipa počinju doživljavati kao srpskopravoslavna. Učinak akulturacijske "devalahizacije" Bunjevaca u Lici i Primorju nije, međutim, uvijek bio uspješan. Posebice se to odnosi na kompaktnija bunjevačka naselja u kojima se njihov tradicionalni vlaškodinarski karakter održao sve do u 19. stoljeće, o čemu slikovito svjedoči i Manojlo Sladović 1856. godine. ${ }^{45}$

\section{BUNJEVCI I VIŠESTRUKI IDENTITETI (Katolische Ratzen - MeERKroaten)}

$\mathrm{B}$ unjevački se etnonim, kao što smo već više puta naglasili, rijetko susreće u povijesnim izvorima. Nazivu Bunjevci alterniraju termini Morlachi catolichi (u Mletačkoj Dalmaciji), Valachi catolichi, Rasciani catolichi, Katolische Ratzen, Iliri, Horvati, Meerkroaten, Likaner (u Hrvatskoj vojnoj krajini),

44 Npr. u župama ličke regimente: Budak (Franić, Marković, Pavičić, Pavletić, Rukavina), Bilaj (Krmpotić, Starčević, Župan), Ribnik (Franić, Jurjević, Rogić, Sekulić, Vranešić, Župan), Udbina (Babić, Franić, Krmpotić, Pezelj, Rosandić, Stanković, Šutija, Tićak). U župama otočke regimente: Donji Kosinj (Vukelić), Perušić (Krunić, Lulić, Rukavina, Sorić, Tomić, Uremović), Čanak (Grbac, Šnjarić), Kuterevo (Babić, Biondić, Rončević, Tomaić, Vukelić), Švica (Biondić, Devčić, Miškulin, Prpić, Rogić, Rupčić), Kompolje (Biondić, Ivanišević, Katalinić, Maras, Perišić, Rukavina, Rupčić, Šimunović, Tomljenović), Prozor (Rogić, Rupčić), Priboj (Čorak, Perišić, Sorić, Šojat), Zavalje (Baričević, Bilen, Perišić, Rogić, Tomljanović). U župama ogulinske regimente: Brinje (Biondić, Kalanj, Rupčić), Drežnik-grad (Čorak, Hodak, Matovina, Rosandić, Rukavina), Vaganac (Barić, Bilen, Knežević, Markezić, Rukavina), Saborsko (Hodak).

45 O razlikama u kulturi i mentalitetu u katoličkih krajišnika u Vojnoj Hrvatskoj sredinom 19. stoljeća Sladović kaže: Pučanstvo prěkogvozdansko jest krajnskog porětla u modruši, munjavi, zagorju, oštarijah, generalskom-stolu i lešću kanošto takovih krajnacah u bilaju, novom, ribniku, brušanih, kosinju, kaludjerovcu i kuterovu imade, što su se poslè povraćene like iza herbersteina naselili. U istih vidi se svuda mnogo pobožni značaj, više mirna krv, radenost i něka obrtnost bilo u gradnji lonacah, čbanah, kopanjah, žlicah, zdèlah ili drugog drvenog posudja kano što su svi bèli gunjac i obće bèlo sukno u odèlu pridržali. Žitelji pako krmpotske satnije, u pazarištih, po lovincu, oko boricevca, brotnje jesu bunjevci od vode bune iz hercegovine potekši čuvajuć i danas uz prkos tolikim nasilnim reformam svoje staro odělo. U onih čuješ i danas kaj amo tamo i kranjska imena, malo pěsamah izim ženskih a u ovih rabe uvěk gusle javorove kano i u podgorju, što se s bunjevci rodjači, nose mrke gunjce i suknje, crvene i modre čarape (kalčine) ili běčve a na glavi platnen rub, koj nasuprot u oštarke i tovunjkinje do najfinije prozorne koprene uzdaje... (Sladović 1856:28-29) 
Raczok, Dalmati, Illiri (u Ugarskoj). To raznoliko nazivlje ukazuje na višestruke aspekte identiteta, od sociostaleških i pokrajinskih do etnojezičnih i etnokulturnih.

Iz razumljivih razloga posebna pozornost pridavana je "raškim" i "hrvatskim" atribucijama. Poznata je činjenica da su habsburške i ugarske vlasti Bunjevce u Podunavlju nazivali između ostalog i rackim imenom ("katolički Raci"), tj. držali su ih dijelom "racke nacije". To nije bila samo percepcija "drugih" već i odraz bunjevačke samoidentifikacije. Dvojna identifikacija Rac-Bunjevac naročito je bila u uporabi u bunjevačkim selima u feherskoj (stolnobiogradskoj) i peštanskoj županiji. (Erdeljanović 1930:345-347) O raširenosti rackoga imena među Bunjevcima svjedočio je i sam Ivan Antunović na vlastitom primjeru iz 1848. (... tada se imena Rac ni u privatnu ni u javnu životu nikad nisam zastidio). (Antunović 1882:120) Jovanu Erdeljanoviću, Aleksi Iviću i drugim srpskim etnolozima i povjesničarima ti su podaci poslužili kao "krunski dokaz" u teoriji o srpskom porijeklu Bunjevaca. I na području Vojne krajine u Hrvatskoj također je zabilježeno nekoliko primjera u kojima se Bunjevci, tj. katolički Vlasi atributiraju raškim imenom. U jednom službenom zapisniku od 13. svibnja 1681. godine dani su iskazi dvojice starješina Vlaha Krmpoćana i jednog stanovnika Ledenica koje je Dvorska komora pozvala da svjedoče o ranijim obvezama stanovnika Liča, Krmpota i Ledenica prema grofovima Zrinskim. Svjedoci Krmpoćani u generalijama naveli su da su Rascijani, pa je u službeni zapisnik upisano: Marcus Perpich de Kernpothi Rascianus" i "Stephanus Duich de dicta Kernpothi itidem Rascianus. (Dabić 2000:107) Na temelju tih "generalija" Vojin Dabić zaključuje: Turdenje navedenih Krmpoćana da su oni Rasciani, kako su u to vreme u službenim spisima nazivani Srbi, otkriva da su oni sami sebe smatrali Srbima. (Ibid.:107-108) Ovdje Dabić krajnje pojednostavljuje problematiku etničke identifikacije. Njegova je teza jednako sporna kao i ona koja za pravoslavne krajišnike u Hrvatskoj 18. i 19. stoljeća nastoji dokazati da su "etnički Hrvati” jer su se svuda vodili kao Croati (pogotovo na europskim ratištima). Raško i srpsko ime zaista su bili sinonimi (Rasciani sive Serviani), međutim u nazivu Rašanin nije bilo toliko pravoslavno-konfesionalnih konotacija kao u srpskom imenu. Te semantičke razlike, u ambijentu interkonfesionalnih suprotnosti, bile su dovoljne da za bunjevačke katolike raško ime bude prijemčivo i manje zazorno od srpskoga. Nadalje, Rašani nisu tada samo etnička oznaka, to je ime koje se odnosi i na pokrajinsku pripadnost i povijesno-geografsko porijeklo. Reminiscencije na "raško razdoblje" povijesti Hercegovine mora da su bile još uvijek žive, što uostalom potvrđuje i sadržaj legende obitelji Rukavina koja izvodi svoje porijeklo od humske vlastele Vladimirovića koju su Nemanjići protjerali iz Raške. ${ }^{46}$

Katolički Vlasi iz zapadne Hercegovine po prvi put su se s hrvatskim imenom susreli u osmanskim krajištima Kliškog sandžaka. Riječ je o provizornoj vojnoupravnoj krajiškoj oblasti - vilajetu Hrvati koje je obuhvaćalo područje osvojeno u Hrvatskoj između 1522. i 1537. godine (prostor između Cetine i Zrmanje, Lika, Krbava, gornje Pounje). Premda je vilajet ukinut vrlo rano, već 1537. godine kada je formiran novi Kliški sandžak, ime "Hrvati" za spomenutu oblast i dalje se povremeno koristilo sve do u 17. stoljeće, te se nekad primjenjivalo i na vlaško stanovništvo. Tako npr. oko 1650. mostarski kadija Ahmed obavještava stanovnike nahija Blato i Broćno da su hrvatski Vlasi (Hrvat Eflakani) koji se kreću po spomenutim nahijama, potrebni jednoga redovnika. (Jurišić 1988:120) Iz izvora proizlazi da je riječ o vlaškoj skupini koja je iz Kliškoga sandžaka prešla u zapadnu Hercegovinu te da su katolici. Čuveni osmanski putopisac Evlija Čelebi prilikom obilaska osmansko-mletačkoga krajišta 1660. godine u vrijeme Kandijskoga rata, vođu šibenskih Morlaka i osmanskog prebjega Cvijana Šarića (inače pravoslavca) naziva "hrvatskim razbojnikom". (Čelebi 1996:185) Tek će s mletačkim osvajanjima "nove" i "najnovije stečevine" od 1684. do 1718. tradicija hrvatskoga imena u tom prostoru biti ozbiljno poljuljana. Ipak arvatstvo će održati kakav-takav kontinuitet u unutrašnjosti Mletačke Dalmacije ("morlačkoj zagori”), pretežno u krugu franjevačke nabožne književnosti.

46 Te reminiscencije u tankom bunjevačkom intelektualnom sloju pothranjivala su djela "baroknog slavizma" prije svega Mavre Orbinija, fra Luke Velimirovića i naročito pjesmarica fra Andrije Kačića Miošića. O legendi obitelji Rukavina pogledati u Rukavina, Goran. “Bog stvori ljude, Ličane i Rukavine.” Vila Velebita. 79-80/1999. 
Hrvatsko se ime najbrže ustalilo kod ličko-primorskih Bunjevaca u Vojnoj krajini. Grof Luigi Marsigli, predsjednik habsburškoga povjerenstva, koje je zajedno s osmanskim povjerenstvom utvrđivalo granicu prema odredbama Karlovačkog mira 1699., za Bunjevce je rekao da su Meerkroaten. (Kaser 2003:21) Time je mislio na stanovništvo Primorske krajine gdje su početkom 18. stoljeća Bunjevci predstavljali značajan dio krajiške populacije. Istražujući protomodernizacijske procese pa tako i one protonacionalne u Vojnoj Hrvatskoj na prijelazu iz 18. u 19. stoljeće, Drago Roksandić ustvrdio je da je militarizacijom Vojne krajine sredinom 18. stoljeća, habsburškim vojnim vlastima bilo veoma stalo da regionalno i regimentski ujednačavaju sve oblike svijesti krajišnika. Upravo njihovim nastojanjem proširena je upotreba pojma "Hrvati” u prostoru nekadašnjega Karlovačkog generalata, kada postaje zemaljskom odrednicom za svo krajiško stanovništvo, katoličko i pravoslavno. (Roksandić, sv. 2 1988:122) Važnu ulogu u tome imala je i senjska Crkva koja je u svom prostoru čuvala hrvatsku kulturnu tradiciju i pod pojmom "Hrvat" sve više podrazumijevala katolika. U pojmu vojnokrajiškog Hrvata iz druge polovice 18. i prve polovice 19. stoljeća preplitala su se tako socijalna, pokrajinska, etnička i konfesionalna značenja.

Kao primjer kako se u ličko-primorskih Bunjevaca hrvatsko ime od odrednice zemaljske (pokrajinske) pripadnosti transformiralo u moderni etnonacionalni identitet mogli bi uzeti poznatu ličku bunjevačku obitelj Starčević iz Velikog Žitnika. Porkulab Miloš Starčević (1656.-?) koji se 1690. godine doselio na područje Pazarišta, bio je u očima komorskih vlasti i Katoličke crkve kao i ostali njegovi suseljani samo katolički Vlah ili Bunjevac, tj. jasno se razlikovao od hrvatskoga stanovništva koje se tada također doseljavalo u Liku. Miloš je bio sudionikom važnih događaja u Lici početkom 18. stoljeća, a njegov sukob s vojvodom Markom Butorcem bio je povod za izbijanje tzv. Ribničke ili Bunjevačke bune 1702. godine. ${ }^{47}$ Miloševi potomci, sinovi Jakov i Matija Starčević 1746. godine postali su kapetanima u novoosnovanoj Ličkoj pukovniji i od tada se uz njihov tradicionalni bunjevački identitet pojavljuje i identifikacija prema svojoj užoj ili regimentskoj (ličkoj) i široj vojnoprovincijskoj ili zemaljskoj (hrvatskoj) pripadnosti. Već je fra Andrija Kačić Miošić u svojoj čuvenoj pjesmarici iz 1756. godine opjevao Jakova Starčevića kao jednog od "vitezova hrvatskih". ${ }^{48}$ Jakovljev unuk Filip Starčević bio je krajem 18. stoljeća seoskim knezom što je tada bila već preživjela funkcija u militariziranoj Vojnoj krajini. Filipov sin, tj. Jakovljev praunuk i Milošev šukununuk bio je Šime Starčević (1784.-1859.) svećenik i jezikoslovac, promicatelj "zemaljskog” i "pučkog" horvatstva da bi već u sljedećem naraštaju, Šimin sinovac Ante Starčević (1823.-1896.) bio utemeljiteljem modernoga nacionalnoga hervatstva. "Klan Starčevića” u modernoj hrvatskoj političkoj povijesti imao je svoj nastavak u djelovanju Davida i Mile Starčevića. Na primjeru Starčevića vidimo kako se u jednoj utjecajnoj bunjevačkoj obitelji u samo jednom stoljeću ukorijenio snažan hrvatski identitet.

Hrvatski nacionalni identitet najsporije i najmukotrpnije se probijao u sredini podunavskih Bunjevaca. I dok je u Lici bunjevaštvo u 19. stoljeću uzmicalo pred hrvatskim nacionalnim imenom, na drugom kraju Monarhije, u južnoj Ugarskoj (Bačkoj) događao se sasvim suprotan proces. Malobrojna inteligencija bunjevačkoga porijekla okupljena u Subotici oko svećenika Ivana Antunovića i Boze Šarčevića kao odgovor na pojačanu mađarizaciju počela je reafirmirati bunjevaštvo, tj. pokreću narodni preporod pod bunjevačkim imenom koje do tada gotovo da i nije bilo u uporabi. ${ }^{49}$ Tek nakon raspada "ugarskog držav-

47 Porkulab pazariški Miloš Starčević prema popisu iz 1712. godine u Pazarištu je posjedovao ukupno 168 štrikova zemlje: "pod kućom”, u Vagancu, Žitniku, "Brizah” te sve počasbine. Imao je tada oko 56 godina, sina Jakova od 20 godina te još pet članova obitelji. (Kaser 2003:343).

48 Ali evo zmaja ognjenoga / po imenu Starčević Jakova! / On na konju Turke razgonjaše, / koga stiza, po poli prisica. ("Pisma druga od vitezova hrvatskih koji viteški vojevaše rata Kandijskoga i Bečkoga” u: Kačić Miošić, Andrija. Razgovor ugodni naroda slovinskoga. Zagreb, 1956, 266). Ovdje sad nije bitno radi li se o Jakovu sinu Miloševom kojeg pjesnik pogrešno stavlja u kontekst Kandijskog i Bečkog rata ili pak o nekom starijem Jakovu (možda ocu Miloševom?). Činjenica jest da Kačić sredinom 18. stoljeća sve prekovelebitske junake u Vojnoj krajini naziva hrvatskim imenom (u pjesmi se uz Starčeviće spominju još i bunjevački rodovi Balenovići, Došeni, Milinkovići i Rukavine).

49 Boza (Ambrozije) Šarčević počeo je u Subotici 1868. godine izdavati Bunjevački kalendar, a Ivan Antunović je 1870. godine u Kalači pokrenuo Bunjevačke $i$ šokačke novine. 
nog okvira” i južnoslavenskoga ujedinjenja 1918. stvoreni su preduvjeti za intenzivniji i uspješniji prodor hrvatske nacionalne ideje i u tu sredinu.

$\mathrm{Na}$ kraju, zanimljivo je promotriti i kako pisci bunjevačkoga porijekla u 18. stoljeću nazivaju svoj jezik. U dalmatinskoj skupini: Tomo Babić (harvatski), Filip Grabovac (ilirički aliti rvacki), Lovro Šitović (hrvatski). U ličko-krajiškoj skupini: Vid Došen (slavonski) ${ }^{50}$, Joso Krmpotić (ilirički). U podunavskoj skupini: Mihovil Radnić (slovinski, bosanski), Emerik Pavić (ilirički, slovinski, dalmatinski), Grga Peštalić (ilirički), Josip Antun Knezović (slovinski).

\section{BUNJEVCI U SVJETLU ONOMASTIKE}

$\mathrm{O}$ nomastička građa (oronimijska, toponimijska i antroponimijska) ukazuje na zastupljenost, raširenost i smjerove prostiranja pojedinoga etnonima. Bunjevačko ime u oronimiji i toponimiji nalazimo na Dinari (Bunjevačko brdo) i Podinarju (Bunjevačko groblje kod Uništa) te na Velebitu (pašnjak Bunjevac). ${ }^{51}$ Većinu bunjevačkih toponimijskih tragova u Lici, Plašćanskom kraju i Gorskom kotaru, u srednjoj Bosni i donjem Podrinju, nalazimo u imenima patronimijskih sela i zaselaka (zaselak Bunjevci u Pothumu kod Plaškog, u Moravicama u Gorskom kotaru, te nedaleko Visokog u Srednjoj Bosni. Oblik Bunijevci javlja se i kao ime zaseoka u Papraći u općini Vlasenica u istočnoj Bosni). Lokalitet Bunjevača na Zavelimu jedini je podatak vezan za područje Hercegovine. Poseban problem predstavljaju pak selo Banjevci istočno od Trebinja, koje Erdeljanović u svojoj monografiji naziva Bunjevci. Radi li se o autorovoj pogrešci ili se to selo zaista tako nekad zvalo trebalo bi tek utvrditi. ${ }^{52}$ Jevto Dedijer, svakako jedan od najupućenijih kad je u pitanju antropogeografija Hercegovine, u svojoj znamenitoj studiji iz 1909. godine nažalost ne spominje ni Bunjevce ni Banjevce. ${ }^{53}$

Poznato je da je nominacija prema etničkoj ili konfesionalnoj pripadnosti rezultat doseljavanja i integracije u drugu etničku ili konfesionalnu sredinu. Prema takvom je porijeklu zajednica najlakše identificirala došljake. (Šimunović 2006:25) Etnici su stoga imali izraženu razlikovnu funkciju u inicijalnoj fazi asimilacije došljaka. Ta onomastička zakonitost našla je svoju potvrdu i u vlaškim zajednicama. Prezimena tipa Bunjevac, Bunjevčić, Bunjevčević i sl., redovito se javljaju u izvanbunjevačkoj sredini, a najčešće kod srpskopravoslavnih vlaških susjeda. Diferencijacijska paradigma bunjevci - rkaći imala je tako i svoju onomastičku refleksiju. Pojedincima ili obiteljima katoličkovlaškog porijekla koji su doselili među pravoslavne nadijevani su nadimci, a potom i prezimena bunjevačke atribucije, a isto se događalo is pravoslavnim Vlasima koji su se doselili među katolike gdje su dobivali nadimke iz kojih su se razvila prezimena tipa Rkać, Rkač, Arkač, Arnjkaš i sl. ${ }^{54}$

50 Vid Došen porijeklom je lički Bunjevac (rođen u Gospiću 1726.), obnašajući svećeničku službu prešao je u Slavoniju gdje se bavio i književnošću.

51 Pašnjak na srednjem Velebitu koji se danas zove Bunovac vjerojatno se nekad nazivao Bunjevac jer ga je pod tim imenom zabilježio i Gospićki ugovor iz 1886. godine o transhumantnoj ispaši na Velebitu.

52 Erdeljanović se poziva na popis austro-ugarskih vlasti iz 1879. godine u kojem je zabilježen zaselak "Bunjevci" kao dio sela Dolovi u općini Arslanagića most. Selo Dolovi sastojalo se od dva naselja, "Bunjevci" i "Pokrajčićc i imalo je ukupno 54 stanovnika pravoslavne vjere (Erdeljanović 1930:305).

53 Povijesni izvori inače potvrđuju postojanje katoličkih enklava u tom prostoru koje nepovratno nestaju u 16. i 17. stoljeću. Kapucin Bernardin Pomazanić koji je 1529. godine iz Dubrovnika putovao u Carigrad, između Bileće i Gackog, i u samom Gackom, našao je mnogo kršćana grčkog obreda, koji su prije bili latini i koji su prešli na pravoslavlje zbog, kako kaže, manjka katoličkih svećenika. Gotovo jedno stoljeće kasnije, 1622. godine fra Benedikt Medvjedović i fra Dominik Andrijašević u predstavci Kongregaciji za propagandu vjere pišu: U Popovu je bilo, nema ni 50 godina, oko 380 (katoličkih) kuća, koje su prešle na raskol, jer nisu imale svoga pastira ni biskupa. I od 12 (katoličkih) crkava, njih 4 prisvojili su raskolnici, ponajviše oni, koji su sami prešli na raskol. (Mandić, Dominik. Hrvati i Srbi dva stara različita naroda. Chicago-Roma-Zürich-Toronto, 1980:263).

54 Biskupska vizitacija iz 1743. godine među katolicima u zapadnoj Hercegovini i jugozapadnoj Bosni bilježi prezimena Rkać, Arkać, Arnjkaš (Pribinovići u Mostarskom blatu, Duvno, Stipanići te Prisoje u Livanjskom polju). U okolici Ljubuškog također postoje katolici s prezimenom Rkač dok kod tamošnjih rodova Džajkića i Draškića postoji predaja da su se u starini prezivali Hrkač i da su došli "od Vrljike" (Čulinović Konstantinović 1989:114). 
U slučajevima prezimena s bunjevačkim predznakom, ograničit ćemo se samo na podatke iz 17 . stoljeća. Najstariji pisani podatak o prezimenu Bunjevac nalazimo u Mletačkoj Dalmaciji za vrijeme Kandijskoga rata. U zabilješci matičnih knjiga iz novigradske i ražanačke župe za 1662. godinu, među Morlacima koji su poginuli u sukobu s Turcima na Otresu spominje se stanoviti Nikola Bunjevac, prebjeg s osmanskoga teritorija. (Desnica I/1950:106) Među stanovnicima Šibenika 1680. godine spominje se također doseljeni Morlak po imenu Nicola Bunieuaz. (Ostojić 1989-1990:275) Na posjedu Zrinskih u Donjim Moravicama 1670. godine spominje se Vlah Manojlo Bunieuach. (Burić 1979:74) U popisu krajišnika Ogulinske kapetanije iz 1699. godine prezime Bunjevac zabilježeno je među vlaškim krajišnicima, "shizmaticima" na području Plaškog (Pothum, Međedak) i Moravica (današnje selo Bunjevci). ${ }^{55}$ Konačno, prezime Bunjevac nalazimo i kod novodoseljenog stanovništva u Slavoniji krajem 17. stoljeća. Kao stanovnik novoosnovanog sela na otoku u Dravi 1697. godine spominje se katolik "Paval Bunyevacz", a u popisu iz 1698. godine u mjestu Selna kod Garčina, sjeveroistočno od Slavonskog Broda, upisana je obitelj Nikole Bunjevca, katoličkog izbjeglice iz Bosne. ${ }^{56}$

Bunjevačka antroponimijska struktura jasno odražava kulturnopovijesne slojeve i etničke asimilacijsko-akulturacijske procese koji su se odvijali u širem dinarskom prostoru još od srednjega vijeka. Uzmimo za primjer prezimena Bunjevaca koja se pojavljuju u popisu Like i Krbave iz 1712. godine. Od 158 evidentiranih bunjevačkih prezimena iz toga popisa, njih oko 30 (20\%) upućuju na starobalkansko (vlaškoarbanaško) porijeklo. Pored prezimena koja su izvedena iz balkanskoromanskog jezičnog naslijeđa (npr. Butorac, Krmpotić, Maras, Paden, Pezelj, Sekulić, Šulentić) nemali broj potječe iz još starijeg, arbanaškog ("ilirskog”) jezičnog sloja. Prema korijenskoj osnovi, arbanaškog su postanja prezimena: Balen, Kalanj, Krišković, Šegota, Šikić, Šolić, Špalj, Šutija. Prema sufiksu -eza: Ivezić, Mikeza, Markeza (danas Markežić), a prema sufiksu -aj: Mataić, Mataija, Suknaić. ${ }^{57}$ Isti popis svjedoči i o značajnim podudarnostima koja su postojala u bunjevačkoj i vlaškopravoslavnoj antroponimiji. Zabilježena su 37 identična oblika prezimena što je svakako odraz njihova zajedničkoga dinarskog sociokulturnog naslijeđa, ali i mnogobrojnih

55 Prezimena Bunjevac i Bunjevčević ("Bunieuchovich”) posebno su učestala kod srpskopravoslavnih na području Vojne krajine u Hrvatskoj. Osim navedenih naselja u Ogulinskoj kapetaniji (kasnije i pukovniji), u 18. stoljeću prezime Bunjevac nalazimo i među pravoslavnim krajišnicima na području Prve i Druge banske pukovnije, u okolici Dvora (Gvozdansko) i Hrvatske Kostajnice (Baćin, Mračaj), a Bunjevčeviće u Slavskom polju u kumpaniji Topusko. Jedinu iznimku predstavlja katolički ("kranjski”) rod Bunjevčevića u Prozoru kod Otočca. U njihovom slučaju možda je riječ o konvertitima s pravoslavlja jer se oko 1700. godine u nedalekom Krasnu i Svetom Jurju spominju "Šizmatici" koji su živjeli izmiješano s katolicima (Bunjevcima) i nisu imali svoga svećenika (Sladović:1856, 49). Uostalom, Bunjevčevići u Kršu kod Kosinja i danas su pravoslavne vjere. O vjerskoj pak pripadnosti porkulaba Janka Bunjevčevića u selu Vilić u Otočkoj kapetaniji iz 1715. godine teško je išta pobliže kazati. (SHK: 1885./III, 307). Erdeljanović 1930:294.; Zirdum, Andrija. Počeci naselja i stanovništvo Brodskog i Gradiškog kraja 1698.-1991., Slavonski Brod, 2001:100. U popisima 18. stoljeća prezimena bunjevačke atribucije nalazimo i na brodskom (Sl. Brod, Selna, Rešetari), gradiškom (Gorice) i požeškom području (Doljanci, Toranj Požeški). Radi se uglavnom o katoličkim, "šokačkim” obiteljima, mahom doseljenicima iz Bosne (Zirdum 2001:82, 247, 282). Trebalo bi tek istražiti u kojim se migracijskim strujama javljaju takva prezimena i koja su njihova ishodišna područja u Bosni odakle sele. U biskupskoj vizitaciji iz 1743. godine u Gornjem Glamočkom polju evidentirano je ime katolika "Matheusa Bunievza". U mjestu Stapar nedaleko Sombora u Bačkoj 1780. godine spominje se pak pravoslavni svećenik “Theodorus Bunyevcsevity”. (Erdeljanović 1930:306).

56 Erdeljanović 1930:294.; Zirdum, Andrija. Počeci naselja i stanovništvo Brodskog i Gradiškog kraja 1698.-1991., Slavonski Brod, 2001:100. U popisima 18. stoljeća prezimena bunjevačke atribucije nalazimo i na brodskom (S. Brod, Selna, Rešetari), gradiškom (Gorice) i požeškom području (Doljanci, Toranj Požeški). Radi se uglavnom o katoličkim, "šokačkim” obiteljima, mahom doseljenicima iz Bosne (Zirdum 2001:82, 247, 282). Trebalo bi tek istražiti u kojim se migracijskim strujama javljaju takva prezimena i koja su njihova ishodišna područja u Bosni odakle sele. U biskupskoj vizitaciji iz 1743. godine u Gornjem Glamočkom polju evidentirano je ime katolika "Matheusa Bunievza”. U mjestu Stapar nedaleko Sombora u Bačkoj 1780. godine spominje se pak pravoslavni svećenik "Theodorus Bunyevcsevity" (Erdeljanović 1930:306).

57 Kod većeg broja vlaških katuna u srednjovjekovnom Humu nalazimo tragove arbanaškog supstrata. O vlaško-arbanaškim amalgamima u Hercegovini svjedoče imena katuna kao što su: Bobani, Burmazi, Gleđevci, Kričke, Maleševci, Mataruge, Zotovići, Žurovići. 
seoba, dodira, miješanja, preplitanja i konverzija. ${ }^{58}$ Prisustvo muslimanskih patronimika u prezimenima podunavskih Bunjevaca krajem 17. i u 18. stoljeću (npr. Alagić, Beširović, Bešlagić, Skenderović, Šabić) kao i znakovito prezime Pokrštenik, govore nam da su u dinamičnu bunjevačku etničku strukturu ulazili i neokristijanizirani segmenti s prostora bivšeg Budimskog ejaleta.

Istražujući povijest seoba i naselja u Lici i Primorju, Stjepan Pavičić je u svojim radovima, koja već spadaju u klasična djela domaće historijske demografije i antroponimije, pokazao da su se s Bunjevcima intenzivno i kontinuirano miješali pojedini nebunjevački i nevlaški elementi. Riječ je o pojedincima i obiteljima koji su dolazili iz agrarnih društava, dalmatinskih distrikata i otoka, $s$ Kvarnera, $s$ vlastelinstava u Primorju (Vinodol, Bakar, Hreljin) i Gorskom kotaru (Brod-Moravice), iz senjske vojničke posade itd. Broj takvih "naturaliziranih" Bunjevaca u 17. i 18. stoljeću i nije bio tako malen. ${ }^{59}$

\section{BUNJEVCI KAO KRAJINSKA ETNIJA: SEOBE, POBUNE I LOJALNOSTI NA TROMEĐI}

$\mathrm{K}$ ao što smo rekli, Bunjevci su se kao prepoznatljiva etnija počeli formirati u okvirima osmanskoga vojnokrajiškog sustava, na prostorima oko Dinare i Velebita u prvoj polovici 16. stoljeća. Nastajući u osebujnim pograničnim uvjetima osmanskoga "serhada", razvili su neke svoje osobitosti koje ih razlikuju od stanovnika njihovih matičnih područja u zapadnoj Hercegovini. Osobitosti društvenopovijesnoga razvoja u prostoru sustjecišta triju imperijalnih sila (Triplex confinium), odrazile su se i na Bunjevce o kojima zato i u stvarnom i simboličnom smislu možemo govoriti kao o "krajinskoj etniji." Seobe, ratna i druga nasilja, pobune i nemiri, socioekonomske i populacijske perturbacije, te ostali dinamični aspekti povijesnoga razvoja na granici, bili su važni čimbenici oblikovanja njihova identiteta. Za Bunjevce u ranome novom vijeku zaista se stoga može reći da je to bio narod koji se mnogo bunio i mnogo selio. Seobe su predstavljale naročito važan faktor usmjeravanja sociodemografskog razvoja i etnokulturnog identiteta. U tom smislu seobe su veoma značajne i s aspekta uporabe bunjevačkog imena. Dok je u krajevima pod Dinarom taj etnonim do modernoga vremena zadržao deprecijativno značenje, u udaljenim krajevima gdje su se iseljavali, gdje više nisu dolazili do izražaja vlaški interkonfesionalni konteksti, i bunjevačko je ime samim tim poprimalo nova značenja.

Prema prostornome određenju možemo razlikovati tri vrste bunjevačkih seoba: migracije iz zapadne Hercegovine u osmanska krajišta Kliškog i Ličkog sandžaka, prekogranične migracije u samom prostoru "Tromeđe", te iseljavanje u Podunavlje. Sve su se te migracije međusobno razlikovale, kako po vremenu trajanja i načinu odvijanja tako i u temeljnim motivima koji su ih pokretali. Bunjevačke seobe bile su dijelom osmanske kolonizacijske politike (tzv. "sürgün”), dio su i "uskočkih" seoba na Tromeđi, a preseljenja u Podunavlje mogu se smatrati nekom vrstom kaznenih deportacija.

Osmansku kolonizaciju na prostoru vilajeta Hrvati, odnosno sandžaka Klis (Turska Hrvatska) u prvoj polovici 16. stoljeća provodili su istaknuti krajiški zapovjednici, sandžak-begovi, vojvode i subaše, Gazi Husrev-beg, Murat-beg Tardić, Malkoč-beg Karaosmanović i Ibrahim-beg. Općenito uzevši, područje Kliškog sandžaka možemo podijeliti u tri glavne vlaške imigracijske zone: a) prekoplaninska koja je obuhvaćala nahije Srb, Unac, Grahovo, Glamoč, Livno i Kupres, gdje su dominirale vlaške zajednice doseljene iz istočne Hercegovine; ${ }^{60}$ b) cetinsko-krčka u nahijama Cetina, Zminje, Petrovo polje, Kosovo, Plavno,

58 Identična prezimena katoličkih Bunjevaca i srpskopravoslavnih Vlaha zabilježena u popisu Like i Krbave iz 1712. bila su: Babić, Despot, Došen, Eror, Grubišić, Ilić, Ivanišević, Jandrijević, Japunčić, Jerković, Jovanović, Kalanj, Knežević, Korica, Komadina, Kovačević, Marković, Matijević, Miletić, Milinković, Milković, Milošević, Pejnović, Radetić, Rogić, Sekulić, Serdar, Stančić, Stanković, Starčević, Suknajić, Tomičić, Vlatković, Vučković, Vukelić, Zorić, Živković.

59 Među takve rodove kod primorskih Bunjevaca, Pavičić ubraja: Biondiće, Grpce, Gržane, Jurčiće, Kocijane, Koliće, Lopce, Mažurane, Miškuline, Rupčiće, Smojvere, Škrgatiće itd. Više o tome u: Pavičić 1962. i Pavičić: 1966:310-378.

60 Izvještaji s hrvatske granice 1524. govore da se u Glamoču i Uncu nalazi “opasno naselje od 6000 vlaških kuća” odakle počinju svi pljačkaški upadi u Hrvatsku i Kranjsku. (Vasić 1963:239) 
gdje je uz većinski doseljene hercegovačke Vlahe bilo i elemenata starosjedilačkog stanovništva; c) zakrčka u nahijama Ostrovica, Zrmanja, Obrovac, Benkovac gdje se u prvoj polovici 16. stoljeća ističe "povratnička” grupacija tzv. Vlaha Istrije. (Šarić 2005:72)

Katolički Vlasi naseljavani su u taj prostor iz zapadne Hercegovine, tj. s područja između donje Cetine i Neretve. U defteru iz 1477. godine u tom je prostoru registrirano ukupno 18 džemata s 429 ognjišta i 69 "neoženjenih" koji su predstavljali posebnu poreznu skupinu. Njihovi katuni (u osmanskoj terminologiji džemati) bili su okupljeni u veće knežinske aglomeracije ("knežine”, "knežije”, "vojvodaluci”), kojima su na čelu bili vojvoda Vladimir u nahiji Mostar i vojvoda Dadoje u nahiji Humska zemlja. Riječ je o zajednicama Vlaha-katolika, novoštokavskoga ikavskoga govora, odnosno o etnodemografskoj osnovi iz koje će se formirati bunjevačka etnija. Pojedini njihovi katuni kao npr. Krmpote, Vojnići i Sladovići, sudjeluju u naseljavanju zapadnoga osmanskoga krajišta tijekom ratnih pohoda i osvajanja područja $\mathrm{Hr}$ vatske od pada Knina 1522. do pada Klisa 1537. godine. Njihove biosocijalne strukture bile su izrazito vitalne što se vidi u slučaju Krmpota i Vojnića koji su svojim novim naseobinama redovito davali svoja "stara katunska" imena. Zbog toga i danas u toponimiji širega prostora Tromeđe kuda su se nekoć kretali, nalazimo po nekoliko "Krmpota" i "Vojnića". Isti je slučaj i s drugim vlaškim skupinama. ${ }^{61}$ Nakon Ciparskoga rata, kliški sandžakbeg Ferhat Sokolović proveo je novu rekolonizaciju područja uz granicu s Mletačkom Republikom i Habsburškom Monarhijom. Tada su se na prostoru zapadno od rijeke Krke ("Zakrčje", "Morlakija") iz nekoliko novodoseljenih vlaškokatoličkih skupina, prije svega krmpotskih, vojničkih i sladovičkih, formirala snažna bunjevačka jezgra. Prema izvješću Vicenza Forze, vikara zadarske nadbiskupije iz studenog 1636. godine, na tom području u 51 mjestu i 6 župa živjelo je oko 13700 katolika, osmanskih podanika. (Jačov 1986:271) ${ }^{62}$ Izbijanje Kandijskoga rata i nove seobe na mletačku i habsburšku stranu, izazvat će i nove velike demografske promjene na tom području.

Vlasi Krmpote (Krmpoćani) predstavljali su jednu izrazito vitalnu i oportunu vlašku grupaciju porijeklom iz zapadne Hercegovine. ${ }^{63} \mathrm{U}$ opširnom defteru za sandžak Hercegovinu iz 1477. godine, džemat Vukića Krmpotića upisan je u nahiji Humska zemlja. Džemat (katun) imao je tada svega 11 kuća kao poreznih jedinica. Naime, iz deftera je vidljivo da su se Krmpote povratile iz zbjega ("od ranije su to bile njihove baštine pa su ponovo došli pod tim uvjetom”), ali očito je da se u trenutku popisa svi još nisu povratili na svoje stare baštine na osmanskom teritoriju. Posjedovali su zimišta u zapadnohercegovačkim mjestima Ledincu, Veselivštaku, Buhovu i Borajni, ${ }^{64}$ dok su im ljetišta bila na planinama Čvrsnici, Vranu i Ljubuši. Osmanlije ih koriste u kolonizacijskoj politici, ali tek će buduća istraživanja osmanskih izvora moći pobliže rasvijetliti njihov seobeni pravac prema zapadu. Zasad, ti se seobeni pravci mogu tek u grubim crtama nazrijeti. Naime, krmpotsku usmenu predaju o svojim seobama na Tromeđi, zabilježio je kapetan gulfa Antonio Civran u svojoj relaciji od 18. ožujka 1615. godine. Predaju je čuo od samih Krmpoćana tijekom pregovora o njihovom preseljenju iz Liča na mletački teritorij. Kapetan Civran tako

${ }_{61}$ U toponimiji Tromeđe trag su ostavile i druge vlaške skupine porijeklom iz Hercegovine, npr. Banjani, Maleševci, Mirilovići, Kričke, Krivošije itd.

62 Prema navedenom izvoru, naselja koja se poimenice spominju kao mjesta u kojima su tada živjeli "Christiani del rito Latino", zapravo Bunjevci bila su: Gorica, Raštane, Prkos, Bubnjane, Lišane Tinjske, Brkljačina Polača, Kamenjane, Podbrđani, Starošane Gornje i Donje, Veliki Prkos, Kašić, Biljane, Korlat, "Boista”, "Abbatia", "Harlichi”, "Milohanich”, Bukvić, Kršulović, Kolarina, "Useazze”, "Bogosaglci”, Bulić, Vukšić, Doljane, Međari, Plastovo, Rupe, Ceranje, Veliki i Mali Pristeg, Dobra voda, Stankovci, Banjevci, Popovići, Krmpote, "Zuzzule”, Parčić i Ervenik. Prije izbijanja Kandijskog rata zna se da je katoličkih Morlaka bilo i na području Jasenice u Morlakiji gdje su im starješine bili Rukavine, te na području Vrane.

63 Porijeklo imena Krmpote nije još sasvim razjašnjeno. Prema Šimunoviću, etimologija je u vezi s lat. osnovom "camp(us)" (polje). Vlaški (rumunjski) vokalni rotacizam kamp>crmp, uz primjenu sufiksa-ota, dao je oblik Krmpota koji bi u prenesenom smislu označavao "one koji žive u polju" (Šimunović 2006:137). Prema Skoku, rum. tj. vlaški "crampot" prilagođena je posuđenica iz praslavenskog kronp, krup (Skok 1972:215). To bi preneseno značilo da su Krmpote "krupni ljudi". Riječje možda nastala i od arbanaškog "kripë" (sol) s obzirom na važnost toga proizvoda u stočarskoj sredini Vlaha.

64 Vidi bilješku 15. 
izvješćuje da su se "Carapotani" pred oko 150 godina doselili u kraj oko Gračaca, ${ }^{65}$ a kako su tamo postali sumnjivi ("in sospetto”), krenuše na područje oko Novigrada gdje su se duže vremena zadržali. Međutim, nakon određenoga vremena dodijalo im je tursko gospodstvo ("che fastiditi dell'Imperio de' Turchi”) i preseliše se u kraj iznad Bakra ("un certo luoco sopra Buccari quindeci miglia”) koje je tada pripadalo habsburškom nadvojvodi. (Ibid.) Komparacija podataka iz mletačkoga izvještaja s podacima osmanskih izvora i arheološkim materijalom na terenu, pružaju nam zanimljive mogućnosti interpretacije. Naime, u selu Kijani kod Gračaca u Lici, nalazi se stećak u obliku križa (u narodu zvan "krstača") koji potječe iz prve polovice ili sredine 16. stoljeća. Na krstači je ćiriličnim slovima uklesan natpis: totu leži Ivan Balenović, sin Mihovilov. (Bašagić 1971:72-73) Sve ukazuje na to da se radi o grobu nekog vlaškog starješine, ime oca upućuje na katolika, a prezime na ugledni krmpotski rod. U osmanskom defteru iz 1528-30. u ličko-pounskom krajištu zaista se i spominje neki vlaški knez po imenu Mihovil koji je tada po nalogu osmanskih vlasti, pusto krajište naseljavao "hajmanima." (Vasić 1963:244) ${ }^{66} \mathrm{Na}$ temelju ovih saznanja, mogli bismo iznijeti pretpostavku prema kojoj su se Vlasi Krmpote iz Hercegovine oko 1528. godine doselili na šire područje Gračaca u Lici. Nešto iza svršetka Ciparskoga rata, osmanska vlast ih naseljava u zaleđe Karina gdje su trebali braniti pravac kojim su se senjski uskoci najčešće koristili tijekom pljačkaških upada na osmanski teritorij. U nahiji Obrovac utemeljili su tada svoje selo Krmpote (danas Medviđa). ${ }^{67}$ Primakavši se tako mletačkoj granici kod Novigrada, mletački ih izvori sve češće registriraju (Morlacchi Caranpotani). Kroz nekoliko desetljeća Krmpoćani su postali nezaobilaznim čimbenikom na tadašnjoj Tromeđi oko Novigradskoga mora, gradeći složene odnose na nemirnoj granici i sa senjskim uskocima kao i s mletačkim zapovjednicima. Krmpoćani su se inače kroz cijelo 17. stoljeće često selili i mijenjali podaništva (priznavali su i cara i cesara i dužda) postavši tako pravom sociodemografskom "paradigmom tromeđe". ${ }^{68}$ Od 1605. do 1647. u nekoliko valova iseljavali su se na habsburško i mletačko područje, najviše u Lič i zaleđe Senja (Sv. Jakov tj. Krmpote, Krivi Put, Ledenice, Senjska Draga), potom u Radovin, Poljica i Vinjerac u zaleđu Zadra, a neki su prelazili i na otok Pag te u Istru. ${ }^{69}$ Jednako tako su se i vraćali, održavajući veze sa svojim starim zavičajem na osmanskom području u nahiji Obrovac. Tijekom Kandijskoga rata 1647. godine, na mletačko područje prešla je i posljednja velika skupina Krmpoćana, osmanskih podanika. Tada je harambaša Njegovan s 40 do 50 obitelji iz Krmpota kod Medviđe, prešao na mletački teritorij naselivši se u Vinjerac i Starigrad, a neki su prešli i na otok Pag (od ovih će neki kasnije prijeći u habsburško podaništvo). Prema već spomenutom izvještaju vikara zadarske nadbiskupije Vicenza Forze od 24. XI. 1636. godine, osmanske Krmpote pripadale su župi Bukovica (Buccovizza) koju su činila sela Krmpote, Popovići, Ervenik, Parčić i Zuzule (?). Cijela župa kojom su upravljali franjevci s Visovca ("fra Zuanne da Vissovaz”) brojala je oko 1180 duša, a u samim Krmpotama živjelo je oko 400 stanovnika. (Jačov 1986:271) Krmpotske se obitelji u isto vrijeme šire i na području Podgorja (Sveti Juraj, Jablanac), a od 1690. godine u značajnoj mjeri sudjeluju i u naseljavanju Like i Krbave. ${ }^{70}$

65 Gli ascendenti di questi popli giá circa 150 anni habitano nel paese di Graz. (CRV, VI/1960:223). Stariji oblik imena Gračac glasio je Gradac pa se vjerojatno to naselje i krije iza Civranovog naziva "Graz".

${ }_{66}$ Terminom haymane (nomadi) u tom su popisu označivane one vlaške skupine koje su se u trenutku popisa nalazile još u fazi naseljavanja, pa kao novi doseljenici još nisu upisani u popis poreznih obveznika. Plaćali su samo porez koji se zvao "resm-i haymane", tj. pristojbu za nomade.

67 U Starom Selu, zaseoku Medviđe, postoji bunar žive vode koji se zove Krmpot. (Pavelić 1991:63)

68 O seobama Vlaha Krmpoćana u 17. stoljeću opširnije u: Pavličević 1989:147-168.

69 U prvoj seobi Krmpoćana u Lič 1605. spominju se ovi rodovi: Balinović (Balen), Barulović, Božić, Budisalić, Butorčić (Butorac), Cvitić, Draganović, Hromić, Kovač, Krivalica, Krmpotić, Krnjac, Malovridnjak, Matijević, Marković, Mihovilović, Mikulić, Miletić, Oproković, Pećanić, Petrović, Skorupović (Skorup), Šimunović, Vukoslavić. Iz druge seobe u Lič iz 1627. nije sačuvan nikakav popis doseljenika, ali Pavličević nakon usporedbi s popisom iz 1605. zaključuje da su se tada mogle doseliti obitelji ili "zadruge": Blažević, Deranja, Filipović, Jovanović, Krpan, Pavelić, Pavličević, Peričić, Prpić, Radošević, Starčević, Šojat, Tomić, Tomičić, Tomljanović i Vukelić. (Pavličević 1989:155)

70 Krmpoćani se najviše naseljavaju na području Pazarišta, Smiljana i Lovinca gdje se susreću s ostalim bunjevačkim migracijskim strujama. 
Vlasi Vojnići bili su katolici porijeklom iz okolice Ljubuškog u zapadnoj Hercegovini. I danas postoji istoimeno selo sjeverozapadno od Ljubuškog, koje je nastalo teritorijalizacijom njihova katuna. Javljaju se još 1408. godine u ispravi bosanskog kralja Stjepana Ostoje kao Vlasi Vojihnići, a pripadali su zapadnohumskoj vlasteli Radivojević-Vlatković. (Dinić 1940: 151, 191) U popisu Hercegovačkog sandžaka 1477. u nahiji Mostar ubilježen je džemat Vukašina, sina Vojihne, koji je tada imao 10 domova i 3 neoženjena. (Aličić 1985:84) Zimovali su i ljetovali zajedno s katunom vojvode Vladimira po zapadnohercegovačkim planinama i župama. Osmanlije ih koloniziraju u zapadna krajišta osvojene Hrvatske, vjerojatno još u prvoj polovici 16. stoljeća. Selo Vojnić kod Trilja možda je bilo njihovo etapno boravište u Kliškom sandžaku. Naime taj toponim nije postojao ranije u srednjem vijeku, a selo se nalazilo na pravcu njihova kretanja prema zapadu. Prema Bogumilu Hrabaku, Vojnići se spominju i na području Dobropoljaca u Bukovici, (Hrabak 1988:187) da bi ih poslije Ciparskoga rata (1573), kliški sandžakbeg Ferhat Sokolović naselio na području svoga novoosnovanoga tinjskog vakufa, uz samu granicu s Mletačkom Dalmacijom. Taj dio Ravnih Kotara uskoro će po njima biti i poznat kao Vojnići, odnosno Županovići, prema njihovim starješinama (Miloš i Filip Županović). Dio Vojnića zajedno s Krmpoćanima sudjeluje u seobi na habsburški teritorij 1605. godine, ali se većina ipak zadržava na prostorima oko Polače i Tinja. ${ }^{71}$ U ljeto 1619. godine starješine Vojnića, Miloš Županović i Mate Vukšić pregovarali su sa senjskim kapetanom o prelasku oko 1500 svojih ljudi na habsburški teritorij, ali do te seobe ipak nije došlo. (Hrabak 1982-1983:391-392) Prema izvješću iz 1636. godine, župu Županovići činilo je šest sela: Gorica, Raštane, Prkos, Bubnjane, Lišane Tinjske i Brkljačina Polača, s ukupno 1550 "duša", a župnikom im je bio dobro poznati svećenik pop (don) Stipan Sorić. (Jačov 1986:268-269) U Kandijskome ratu, 1647. godine, Vlasi Vojnići u cijelosti prelaze u mletačko podaništvo te se dio s knezom Filipom Županovićem naseljava u Valturu kod Pule. Zanimljivo bi bilo istražiti u kakvoj su vezi kotarski Vojnići i ugledan subotički rod Vojnića koji su 1741. stekli ugarsko plemstvo. ${ }^{72}$

O Vlasima Sladovićima zna se najmanje. U osmanskom defteru iz 1477. godine ubilježen je u nahiji Mostar, dežmat Milosava, sina Sladića od 19 domova. Riječ je o osobitom džematu koji je bio organiziran po selima te se uz njih ne navode ni planinska ljetišta ni župska zimišta kao kod ostalih vlaških skupina iz popisa. Te činjenice upućuju na dva moguća zaključka: ili se, u socijalnom smislu, radilo o "vlahiziranom" seoskom stanovništvu na koje je osmanska vlast prenijela vlaški status, ili je pak riječ o potpuno "teritorijaliziranom” vlaškom katunu. Sela u sastavu džemata bila su: Podci (vjerojatno selo Podaca u Makarskom primorju), Igre (današnje Igrane na Biokovu) i Kozica (selo pod Biokovom u Vrgoračkoj krajini). Ova vlaška skupina također je sudjelovala u seobama na zapad. Početkom 17. stoljeća Vlasi Sladovići kreću se na širem prostoru Morlakije (Bukovica, Podgorje), a starješinom im je bio vojvoda Gvozden Sladović, pa je ta grupacija poznata i kao "Gvozdenovi ljudi”. Oni 1605. godine s Vlasima Krmpoćanima sudjeluju u preseljenju s osmanskog teritorija u mjesto Ličc, na zrinskom vlastelinstvu Hreljin u Hrvatskoj. U skupini Gvozdenovih ljudi tada je bilo 20 obitelji. ${ }^{73}$ Njihova se sudbina od tada potpuno veže uz jaču krmpotsku granu. Neki od Sladovića priključit će se kasnije posadi senjske kapetanije, a izdanak te grane vjerojatno je i povjesničar Manojlo Sladović. ${ }^{74}$

Demografska povijest Bunjevaca u 16. i 17. stoljeću u značajnoj je mjeri oscilirala duž bipolarnog koridora, dinarski jugozapad-podunavski sjeveroistok. Izgleda da najranije seobe u Podunavlje datiraju iz prve polovice 16. stoljeća, a povezane su s nemirima i nezadovoljstvom vlaških zajednica koji tada izbijaju

71 S Krmpoćanima se u Lič naselilo 15 obitelji Vojnića. Njihova su prezimena: Božić, Galešić, Jurjević, Matijević, Pavličić, Petković, Stojčević, Vojnić, Vojnović.

72 Prema Anti Sekuliću, subotički Vojnići potječu iz Dalmacije, a 1687. godine njezini su članovi bili navedeni među subotičkim graničarima. (Sekulić 1986:246)

73 Kućedomaćini se poimenično spominju, a zastupljena su sljedeća prezimena: Balinović, Brošković, Ilnić, Karanović, Lovrić, Martinović, Mihovilović, Mikulić, Sladović, Veljanić, Vilenica.

74 Senjski Sladovići naselit će se i u Otočkoj kapetaniji, najviše u Ličkom Lešću gdje ih i danas ima. 
na osmanskim krajištima. Naime, nešto poslije Mohačke bitke 1526. godine osmanske vlasti ukinule su Vlasima poseban status i izjednačile ih s običnom rajom. Izgleda da je osvajanje Ugarske iziskivalo velike financijske troškove, pa osmanska država više nije bila spremna priznavati porezne olakšice značajnom dijelu stanovništva, posebice kršćanskim zimijama. Pokušaj pravne nivelacije vlaške s običnom rajom pokazao se financijski i ekonomski neuspješnim, a politički štetnim projektom. Ukidanje posebnog vlaškog statusa izazvalo je velike nemire i prve masovne seobe iz osmanskih pograničnih krajeva u susjedne, neprijateljske zemlje. Od proljeća 1530. počela su velika komešanja i među tek naseljenim vlaškim skupinama u području vilajeta Hrvati. S područja gornjeg Pounja, Unca, Glamoča, Grahova, Knina i Cetine, vlaške skupine tada u velikom broju prelaze ("uskaču") u Hrvatsku i Kranjsku i sele se uglavnom na Žumberak i Kras u Istri. U osmansko-mletačkom ratu (1537.-1540.) veliki dio Vlaha prelazi i na mletački teritorij u pravcu Zadra, od čega će mnogi biti prebačeni u Istru. Godine 1533. izbila je i vlaška pobuna u zapadnom dijelu Hercegovačkog sandžaka. Prema jednom osmanskom fermanu iz 1564.-65. proizlazi da su Osmanlije već 1530-ih s područja vilajeta Hrvati preseljavali buntovni vlaški element u Podunavlje. Naime, jedna takva skupina se 30-ak godina nakon seobe, uz dozvolu osmanskih vlasti povratila u stari zavičaj. ${ }^{75}$ Sve okolnosti tih najranijih seoba u Podunavlje nisu još dovoljno poznate. U svakom slučaju, spominjanje kneza Vraneša Ivanovića i njegove knežine 1581. godine u okolici Kalače, ili postojanje škole za "Dalmatince" u Temišvarskoj biskupiji, koju je 1582. otvorio bosanski franjevac fra Anto Matković, govore u prilog činjenici da su u prostoru srednjeg Podunavlja, tj. Segedinskog, a i Budimskog beglerbegluka već u 16. stoljeću postojale stanovite dinarske sociokulturne strukture. (Fermedžin 1892:319; Bušić 2005:51) Međutim, najvažnije seobe Bunjevaca u Podunavlje dogodile su se početkom 17. stoljeća. Nove masovne seobe bile su rezultat nezadovoljstva vlaških skupina svojim novim statusima na krajištu, ali i reakcija na sve veće zloporabe u redovima provincijske upravljačke elite. Kao posljedica pobuna protiv "pljačkaške uprave” sandžak-begova u Kliškom i Ličkom sandžaku između 1603. i 1620. dolazi do iseljavanja velikih skupina u pravcu Podunavlja. Zbog još uvijek malobrojnih izvora, samo se u grubim crtama mogu pratiti seobe Bunjevaca u Bačku. Šibenski knez je 1608. javio mletačkom Senatu da je 2 000 morlačkih kuća preseljeno preko Dunava, kako bi se oslobodili tiranije Turaka, koja je poprimila takve razmjere da se ne može više trpjeti. Bio je to epilog pobune drniških muslimana i Vlaha, koje je predvodio drniški aga Mehmed Terzibašić. ${ }^{76}$ Osmanska vlast upravljala je i zapravo poticala seobe Bunjevaca u Podunavlje, prije svega kako bi razrijedila buntovničku masu i stabilizirala prilike na granici. Dodatan razlog naseljavanja u Podunavlje svakako je bila i opustošenost toga područja nakon Dugoga ("panonskog") rata. Naime, na poziv habsburških vojnih vlasti 1598. iselilo je iz bajske, somborske i subotičke nahije 39 sela s 15000 stanovnika. Ti su se Srbi ("Raci”) na poticaj Miklósa Pálffya naselili u okolici Ostrogona. (Ivić 1929:210-211) Upravo u te opustjele nahije Budimskog beglerbegluka, Turci su po svršetku Dugog rata (Žitvanski mir 1606.) počeli naseljavati Bunjevce. Bunjevački Vlasi ta preseljenja pak nisu nužno morali doživljavati samo kao kaznenu mjeru deportacije, već i kao dobrodošlu priliku da se oslobode pritisaka "tatarske dinastije" u Kliškom sandžaku, kao i "dinastije Memibegović" u susjednom Ličko-krčkom sandžaku. ${ }^{77}$ Athanasio Georigiceo zabilježio je 1626. da je ta selidba "preko Dunava" uslijedila ponajviše iz straha od Mehmed-bega i njegova oca. (Batinić 1885:116-150) Tradicija seoba Bunjevaca u Podunavlje bila je očito uspostavljena već u 16. stoljeću, tako da preseljenje u taj daleki kraj nije moralo nužno značiti i put u neizvjesnost. Seoba iz Kliškog sandžaka bilo je i sljedećih godina, npr. 1619. godine kad sudjeluju

75 O reverzibilnim migracijama na pravcu dinarski prostori - Podunavlje svjedoči i podatak iz 1563. godine, kada se tražilo prisilno preseljavanje nekoliko stotina obitelji (vjerojatno vlaških) iz Podravine, nazad u Hercegovinu radi suradnje s neprijateljem. (Moačanin 1999:96, 98)

76 Bune i nemiri koji su još za trajanja Dugoga rata zahvatili sandžake Klis, Krku i Hercegovinu, u kojima je razmjerno često dolazilo do suradnje Vlaha i nižih muslimanskih slojeva u otporu prema uvelike osamostaljenoj osmanskoj provincijskoj upravljačkoj eliti, istraživački još uvijek nisu dovoljno vrednovane. Više o tome u: Šarić 1999:70-126.

77 Kliški sandžak-begovi Mustafa-beg i njegov sin Mehmed-beg protiv kojih su se bunili Bunjevci u prvoj polovici 17. stoljeća bili su tatarskog porijekla. 
i srpskopravoslavni Vlasi koji s kaluđerima iz manastira Dragović sele u Grabovac u Baranji. Seljenje nije zahvaćalo samo područje uz rijeku Dunav, već izgleda i ona zapadnija u Požeškom i Pakračkom sandžaku, na što ukazuje i izmijenjena onomastička struktura stanovništva i naselja u tim prostorima. ${ }^{78}$ Georgiceo zaključuje 1626. godine da raja već 25 godina iz Kliškog sandžaka neprestano bježi čiji se broj u razdoblju od 1600. do 1624. smanjio za trećinu (tvrdi da je ranije u sandžaku bilo oko 30000 kuća, a do njegove vizitacije taj se broj smanjio za 10 000). (Batinić 1885:142) Zasad se mogu ustanoviti iseljavanja jedino iz područja Drniša (Petrovo polje), Vrlike i Livna, ali imigracijska ishodišta bila su sigurno znatno šira. Imena nekih naselja koja se javljaju sredinom 17. stoljeća uz rijeku Krivaju kod Subotice već jasno ukazuju na dinarsku migraciju (npr. Kupuszina, Stanisics, Zobnatica).

Uz seobe u Podunavlje vežu se inače i prvi pisani podaci o upotrebi bunjevačkoga imena. Tako primjerice u osmanskom defteru za sandžak Mohač (Baranja) iz 1554. u selu Márok navodi se ime stanovitog seljaka-rajetina Martona Bunavca (u mađ. grafiji Márton Bunavácz) koji je kao Martin Bunivac (u mađ.

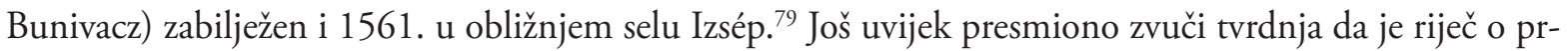
vome spomenu bunjevačkog imena i to barem iz dva razloga ${ }^{80}$ Prvo, teoretski je da je moguće da se radi o pogrešnoj transkripciji s osmanskoturskoga jer se prezime moglo čitati i drukčije, npr. Dunavac. ${ }^{81}$ Drugi je razlog, ukoliko prezime i jest bunjevačke atribucije, da se ipak radi o etniku, imeničkoj tvorbi koja u pravilu nastaje u drugoj sredini u odnosu na sadržaj atribucije, pa prema tome spomenuti Martin nije mogao biti Bunjevac. Međutim, drugi podaci iz istog deftera svjedoče nam da je tada u Baranji moralo biti stanovništva koje je doseljeno iz južnih dinarskih prostora. Naime, na više mjesta u navedenim popisima iz 1554. i 1561. upisani su pripadnici raje kojima uz ime stoji oznaka Hirvat kao npr. u selima Sukit (mađ. Szőkéd) i Ata (mađ. Áta). (Šarošac 1991:16, 32) U osmanskoj terminologiji 16. stoljeća, oznaka "Hrvat" za osmanskog podanika mogla se odnositi samo na ono stanovništvo čije je regionalno porijeklo bilo iz nekadašnjeg vilajeta Hrvati u Kliškom sanžaku (ukinutog 1537.), odnosno, upravo iz onog prostora odakle su se u Podunavlje iseljavali i Bunjevci. Uostalom, tradicija pravoslavnoga manastira u Grabovcu govori da su ga 1585. godine osnovali kaluđeri iz manastira Dragović na Cetini u Kliškom snadžaku.

Prvi nedvojbeni pisani spomen imena Bunjevci veže se uz seobe u 17. stoljeću, tj. od 1608. godine pa nadalje. Misionar don Šimun Matković ${ }^{82}$ uputio je 1622. molbu Kongregaciji za propagandu vjere u Rim, u kojoj je tražio da mu se dodijeli župa Bunjevci u nadbiskupiji kaločkoj (parochiam Bunievczi archidioecesis Colocensis). U literaturi ne postoji slaganje o tome je li riječ samo o jednoj od bunjevačkih župa ili o župi u kojoj su bili okupljeni svi Bunjevci s područja sjeverne Bačke. Najvjerodostojnijom se čini pretpostavka B. Bukinca da je to oznaka šire zajednice, a ne jednog naselja. U izvješću barskog nadbiskupa iz 1633., navodi se "parochia di Backa" u kojoj su djelovali franjevci provincije Bosne Srebrene, a obuhvaćala je 400 zaselaka u kojima živio narod koji govori "ilirički” (de lingua illirica). (Fermendžin 1890:411)

Seobe - toliko svojstvene vlaškom svijetu - utjecale su i na konverzije odnosno promjene konfesionalnog identiteta. Tijekom migracija često se razbijala koherencija vlaških grupa i u zoni doseljavanja stvarao mozaik novih vlaških grupa različitoga porijekla. U takvim situacijama, socijalna akomodacija mogla je

78 U Dugom ratu, veliki broj Vlaha sa slavonskog "sehada” (Mala Vlaška) prebjegao je u Varaždinski generalat, zbog čega je pokrenuta nova rekolonizacija tih prostora (Moačanin, Nenad. Slavonija i Srijem u razdoblju osmanske vladavine. Slavonski Brod 2001:132, 136.)

79 Velics, A. L. Magyarországi török kincstári defterek. II, Budapest 1890:398.; usp. Erdeljanović 1930:61-63.

80 Erdeljanović također oprezno odbacuje taj podatak smatrajući da se radi o nespretnom čitanju kmetova imena.

81 Za ovu sugestiju zahvaljujem kolegici mr. sc. Korneliji Jurin Starčević. Osmanski defteri inače vrlo rijetko bilježe prezimena, standardni opis sastojao se od imena poreznog obveznika uz koje je stajalo i očevo ime. S obzirom pak da je popisivač unosio slavenske nastavke -avac/-evac, izgleda da mu južnoslavenski idiomi nisu bili nepoznati.

82 Simeon Joannis Matcovich Bosnensis et in patribus Serbiae, Slavoniae et Hungariae australis, Turcae subiectis, missionaries. (Fermendžin 1892:367) 
dovesti do vjerskih konverzija, naravno iz one manjinske u onu većinsku. ${ }^{83}$ Podatke o masovnom prevjeravanju s pravoslavlja na katolicizam u zoni kretanja Bunjevaca, samo za 17. stoljeće, nalazimo u izvješćima zagrebačkoga biskupa Benedikta Vinkovića iz 1639. (za Krmpote, Istru, Kras), vojnog kapelana, kapucina fra Bartolomeja iz 1649. (za zadarsko i šibensko zaleđe), splitskog nadbiskupa Leonarda Bondumeria iz 1663. (za područje Klisa i Vranjica) i ninskog biskupa Juraja Parčića iz 1692. (za Posedarje, Ražanac i “Morlakiju”). (Dabić 2000:108; Bogović 1993:107-108, 167-170) Ipak, usprkos uznapredovanom procesu etnokonfesionalizacije, u 17. su stoljeću još postojale "heterodoksne" vlaške grupacije. Jedna od njih bila je i krmpotska. Prilikom naseljavanja Liča, početkom 17. stoljeća među Krmpoćanima bio je stanovit broj pravoslavnih obitelji, međutim kako na području njihova novog naseljavanja nije postojala "pravoslavna infrastruktura”, taj će element uskoro sasvim nestati. Jedno stoljeće kasnije, oko 1700. godine Krmpoćani su bili potpuno homogena katolička zajednica. ${ }^{84}$ Povijesna antroponimija potvrđuje takvu praksu. Vlaško-bunjevačka onomastika prilično je ujednačena tako da brojna prezimena nalazimo i kod katolika i kod pravoslavaca, a tome svakako razlog treba tražiti u vjerskim prijelazima, a posredno i u seobama. ${ }^{85}$

\section{IZVORI I LITERATURA:}

ALIČIĆ, Ahmet (1985): Poimenični popis sandžaka vilajeta Hercegovina. Sarajevo.

ANDERSON, Benedict (1990): Nacija zamišljena zajednica. Razmatranja o porijeklu i širenju nacionalizma. Zagreb.

ANDRIĆ, Jasna (1988): Nadimak "Rkać (Rkač). Etnološka tribina, 2:43-58, Zagreb.

ANTUNOVIĆ, Ivan (1882): Razprava o podunavskih i potisanskih Bunjevcih i Šokcih u pogledu narodnom, vjerskom, umnom, gradanskom i gospodarskom. Beč.

BATINIĆ, Mijo (1885): Nekoliko priloga k bosanskoj crkvenoj povijesti. U: Starine JAZU. sv. 17, Zagreb.

BERTOŠA, Miroslav (1986): Mletačka Istra u XVI. i XVII. stoljeću i kolonizacija (teme i problemi). Pula.

BERTOŠA, Miroslav (2002): Je li etnologija teritorij povjesničara. U: Izazovi povijesnog zanata. Lokalna povijest $i$ sveopći modeli. Zagreb, 297-311.

BEŠLAGIĆ, Šefik (1971): Stećci. Kataloško-topografski pregled. Veselin Masleša, Sarajevo.

BJELANOVIĆ, Živko (1987): Toponimija Benkovačkog kraja kao ogledalo njegove prošlosti. U: Benkovački kraj kroz vjekove. Zbornik 1. Benkovac, 171-185.

BLAGOJEVIĆ, Miloš (1989): Krajišta srednjovekovne Srbije. U: Čubrilović, Vasa. (ur.). Vojne krajine u jugoslovenskim zemljama u novom veku do Karlovačkog mira 1699. Beograd, 27-46.

BOGOVIĆ, Mile (1993): Katolička crkva i pravoslavlje u Dalmaciji za mletačke vladavine. Zagreb.

BUKINAC, Beato Stjepan (1940): De activitate franciscanorum in migrationibus populi croatici. Saeculis XVI. et XVII. Zagreb.

BURIĆ, Antun (1979): Povijesna antroponimija Gorskog kotara u Hrvatskoj. Goranska prezimena kroz povijest. Rijeka.

83 Naseljavajući mletački teritorij u Dalmaciji i Istri u 16. stoljeću, brojne vlaške skupine bile su izložene akulturacijskim utjecajima, pri čemu nisu samo prelazili na novu vjeru (u slučaju pravoslavnih), već su se postupno integrirali u novu distriktualnu protourbanu sredinu, gubeći svoje vlaško socijalno biće. Rezultat je to širih društvenih, političkih, gospodarskih i ekosistemskih okolnosti, a nadasve politike Venecije, koja do sredine 17. stoljeća (Kandijski rat), nije bila voljna vlaškim prebjezima s osmanskoga područja priznati društvenopravni individualitet, tj. posebnu pravnu kategoriju. (usp. Šarić 2005.)

84 O mulitkonfesionalnim aspektima u Krmpoćana pisali su: Sladović 1856:435.; Roksandić 1982:39. i Pavličević 1989:162-166.

85 Prijelazi katolika na pravoslavlje nisu dovoljno dokumentirani, ali i njih je svakako bilo na područjima pod osmanskom vlašću. U popisu Like i Krbave 1712. među srpskopravoslavnim Vlasima nalazimo prezimena koja su po svome postanju "zapadnokršćanske" provenijencije, kao npr.: Jerković, Jurasović, Marinković, Mihovilović. 
BURIĆ, Josip (2002): Biskupije Senjska i Modruška u XVIII. stoljeću. Gospić-Zagreb.

BUŠIĆ, K. (2005): Bunjevci. U: Leksikon podunavskih Hrvata-Bunjevaca i Šokaca. Sv. 4:46-53. Subotica.

CLIFORD, James (1988): The predicament of culture: Twentieth-century ethnography, literature, and art. Harvard University Press.

Commissiones et Relationes Venetae (1970): (prir. Grga Novak), tomus VI., Zagreb.

ČELEBI, Evlija (1966): Putopis. Odlomci o jugoslovenskim zemljama, Sarajevo.

ČULINOVIĆ KONSTANTINOVIĆ, Vesna (1989): Život i socijalna kultura stočarskog stanovništva pod Dinarom. U: Zbornik za narodni život i običaje Južnih Slavena, knj. 51:109-182, Zagreb.

DABIĆ, S. Vojin (2000): Vojna krajina. Karlovački generalat (1530-1746). Beograd.

DESNICA, Boško (1950): Istorija kotarskih uskoka 1646-1684. sv. I, Beograd.

DINIĆ, M. (1940): Zemlje hercega sv. Save. Glas SAN, knj. 82, Beograd.

DŽAJA, Miroslav; DRAGANOVIĆ, Krunoslav (1994): Sa kupreške visoravni. Baško Polje - Zagreb.

DŽAJA, M. Srećko (1999): Konfesionalnost i nacionalnost Bosne i Hercegovine. Predemancipacijsko razdoblje 1463.-1804. Mostar.

DŽENKINS, Ričard (2001): Etnicitet u novom ključu-argumenti i ispitivanja. Beograd.

ERDELJANOVIĆ, Jovan (1930): O poreklu Bunjevaca. Beograd.

FERMENDŽIN. Euzebije (1892): Acta Bosnae potissimum ecclesiasticacum insertis editorum documentorum regestis ab anno 925 usque adannum 1752... Zagreb.

FISHMAN, A Joshua (1978): Sociologija jezika. Interdisciplinarni društvenonaučni pristup jeziku u društvu. Sarajevo.

FORTIS, Alberto (1984): Put po Dalmaciji. (prir. Josip Bratulić), Zagreb.

GASHI, Skënder (1982): Albansko-vlaška simbioza u svjetlu onomastike. U: Onomastica Jugoslavica. 10:47-62. Zagreb.

GROSS, Mirjana (1996): Suvremena historiografija. Korijeni, postignuća, traganja. Zagreb.

HACQUET, Balthazar (1802-1805). Abbildung und Beschreibung der südwest und östlichen Wenden, Illyrer und Slaven.

HERŠAK, Emil (1999): Etničnost u prošlosti. U: Etničnost i povijest, Zagreb, 25-35.

HOBSBAWM, Eric J. (1993): Nacije i nacionalizam. Program, mit, stvarnost. Zagreb.

HRABAK, Bogumil (1981): Razgranjivanje katuna i stvaranje trupe katuna odnosno plemena u nekadašnjoj Hercegovini (XIII.- XV. vek). U: PEJOVIĆ, Đoko. (ur.). Predmet i metod izučavanja patrijarhalnih zajednica u Jugoslaviji, Titograd, 181-201.

HRABAK, Bogumil (1982-1983): Neuspjelo naseljavanje Krmpoćana na Kvarneru, u Istri i Dalmaciji 1614.-1615. godine. Jadranski zbornik, 12:365-394, Pula-Rijeka.

HRABAK, Bogumil (1988): Vlaška i uskočka kretanja u severnoj Dalmaciji u XVI. stoleću. Benkovački kraj kroz vijekove. Zbornik 2:107-258, Benkovac.

HRABAK, Bogumil (1997): Čelnici stočarskih zajednica u istočnoj Hercegovini u XIII-XV veku. Zbornik za istoriju Bosne i Hercegovine. 2:139-172. Beograd.

IVANOVIĆ, R. (1951-1952): Dečanski katuni. Istoriski časopis. 3:257-266, Beograd.

IVIĆ, Aleksa (1929): Istorija Srba u Vojvodini, Novi Sad.

JAČOV, Marko (1986): Spisi Kongregacije za propagandu vere u Rimu o Srbima 1622-1644. sv. I, Beograd.

JURIŠIĆ, Karlo (1972): Katolička crkva na Biokovsko-neretvanskom području u doba turske vladavine. Zagreb.

JURIŠIĆ, Karlo (1988): Regesta turskih dokumenata o franjevačkom samostanu u nahiji Imota. Franjevacki samostan Imotski 1738-1988, Imotski.

KASER, Karl (2003): Popis Like i Krbave 1712. godine. Obitelj, zemljišni posjed i etničnost u jugozapadnoj Hrvatskoj. Zagreb. 
KLAIĆ, Vjekoslav (1899): Povijest Hrvata: od najstarijih vremena do svršstka XIX. stoljeća, sv. V., Zagreb. LANOSOVIĆ, Marija (1794): Evangjelistar illiricski... Budim.

LAZANIN, Sanja (2002): Slika Drugog i pismo o Sebi. Josip Rabatta (1661-1731) o Hrvatskoj i sebi. Magistarski rad Filozofskog fakulteta Sveučilišta u Zagrebu.

MOAČANIN, Nenad (1999): Turska Hrvatska. Zagreb.

MURGIĆ, Ivan (1882): Uspomene na gornju Krajinu s osobitim obzirom na Bunjevce. Vienac, zabavi i pouci, god. XIV., br. 2-8, Zagreb.

NOVAK, Grga (1971): Morlaci (Vlasi) gledani s mletačke strane. Zbornk za narodni život i običaje Južnih Slavena, 45:579-603, Zagreb.

OSTOJIĆ, Ivan (1989-1990): Onomastika šibenskoga kraja (III). Kačić. Zbornik franjevačke provijcije Presvetoga otkupitelja. sv. XXI-XXII:263-340, Split.

PAVELIĆ, Rikard (1991): Stope predaka. Bunjevci u Hrvatskom primorju, Gorskom kotaru i Lici. Rijeka.

PAVLIČEVIĆ, Dragutin (1989): Seobe Vlaha Krmpoćana u XVII. stoljeću. U: Vojne krajine u jugoslovenskim zemljama u novom veku do Karlovačkog mira 1699, Beograd, 147-168.

PAVIČIĆ, Stjepan (1962): Seobe i naselja u Lici. Zbornik za narodni život i običaje Južnih Slavena, knj. 41:5-330, Zagreb.

PAVIČIĆ, Stjepan (1966): Raseljenje starosjedilaca i doseljenje Bunjevaca u senjski kraj. Senjski zbornik, 2:310-378, Senj.

PUTINJA, Filip; STREF FENAR, Žoslin (1997): Teorije o etnicitetu. Beograd.

ROKSANDIĆ, Drago (1982): Bune u Senju i Primorskoj krajini (1719-1722). Radovi Instituta za hrvatsku povijest, 15, Zagreb.

ROKSANDIĆ, Drago (1988): Vojna Hrvatska. La Croatie Militaire. sv 2, Zagreb.

ROKSANDIĆ, Drago (1991): Srbi u Hrvatskoj od 15. stoljeća do naših dana. Zagreb.

ROKSANDIĆ, Drago (2003). Triplex Confinium ili o granicama i regijama hrvatske povijesti 1500-1800. Zagreb.

ROKSANDIĆ, Drago (2002): Etnos, konfesija, tolerancija. Zagreb.

SEKULIĆ, Ante (1986): Narodni život i običaji bačkih Bunjevaca. Zbornik za narodni život i običaje Južnih Slavena, knj. 50:5-474, Zagreb.

SKOK, Petar (1972): Etimologijski riječnik hrvatskog ili srpskog jezika. II, Zagreb, 215.

SLADOVIĆ, Manojlo (1856): Pověsti biskupijah Senjske i Modruške ili Krbavske. Trst.

SMITH, A. D. (1988): Social and cultural conditions of ethnic survival. Journal of Ethnic Studies, 21, Ljubljana.

Spomenici Hrvatske krajine. (prir. Radoslav Lopašić), Zagreb, III/1885.

ŠARIĆ, Marko (1999): Društveni odnosi i previranja u sandžaku Lika-Krka u 16. i početkom 17. stoljaća. U: Diplomska radionica 1 prof. dr. Drage Roksandića, Zagreb, 67-128.

ŠARIĆ, Marko (2005): Dinarski Vlasi između Osmanskog Carstva i Venecije. Povijest pravnih institucija jednog krajiškog društva (15-17. st.). Magistarski rad Filozofskog fakulteta Sveučilišta u Zagrebu.

ŠAROŠAC, Đuro (1991): Bosanski Hrvati u okolici Pečuha - ekonomska osnova seoskog života. Budapest.

ŠIMUNOVIĆ, Petar (2006): Hrvatska prezimena. 3. izd., Zagreb.

VASIĆ, Milan (1964): Etnička kretanja u Bosanskoj krajini u XVI. vijeku. Godišnjak društva istoričara $\mathrm{BiH}, 14: 11-65$, Sarajevo.

ZIRDUM, Andrija. (1982): Filip Lastrić Oćevac 1700-1783. Prilog kulturnoj povijesti Bosne i Hercegovine, Zagreb. 